\title{
Yucca Mountain Site Characterization Project Plan
}

January 1992

U.S. Department of Energy Office of Civilian Radioactive Waste Management Washington, DC 20585 MASTER 


\section{OFFICE OF CIVILIAN RADIOACTIVE WASTE MANAGEMENT PROGRAM CHANGE CONTROL BOARD DIRECTIVE}

(Amended)

$\begin{array}{lll}\text { (1) DCP NUMBER: } & \text { (2) DCP TITLE: } & \begin{array}{l}\text { Approval of Yucca Mountain Site } \\ \text { Characterization Project Plan }\end{array}\end{array}$

(3) DOCUMENT NUMBER: DOE/RW-0313 (4) COGNIZANT ORGANIZATION: OGD, RW-20 REVISION: 0 DOCUMENT TITL: Yucca Mountain Site Characterization Project Plan

(5) DCP DISPOSITION:

$\begin{array}{ll}\square & \text { APPROVE } \\ \text { [D } & \text { APPROVE WITH CONDITIONS }\end{array}$

$\begin{array}{ll}\square & \text { DISAPPROVE } \\ \square & \text { ACTION DEFERRED } \\ \square & \text { CANCELLED/WITHDRAWN }\end{array}$

(6) CONDITIONSRATIONALE:

Since my initial Directive approving DCP-41 on $8 / 13 / 91$, the document has been reviewed by ESAAB staff. That review and the passage of time have necessitated a number of changes to bring the document up to date and to improve its accuracy, including changes to the Program Cost and Schedule Baseline resulting from the approval of DCP-50.

\section{(7) IMPLEMENTATION DIRECTION:}

1. The Associate Director for Geologic Disposal (RW-20) shall incorporate the attached changes into the Yucca Mountain Site Characterization Project Plan and resubmit the revised document to the Associate Director for Program and Resources Management (RW-10) for transmittal to ESAAB principals for concurrence.

2. Following concurrence by ESAAB principals, the PCCB Executive Secretary shall finalize the document for signature by the Director, OCRWM (RW-1), who shall present it to the Acquisition Executive through PR-24, for final approval。

3. Printing and distribution of the final document shall follow Acquisition Executive approval.

(8) CONCURRENCE: (IF REQUIRED)

DATE:
$\mathrm{N} / \mathrm{A}$ DIRECTOR, OQA
(9)

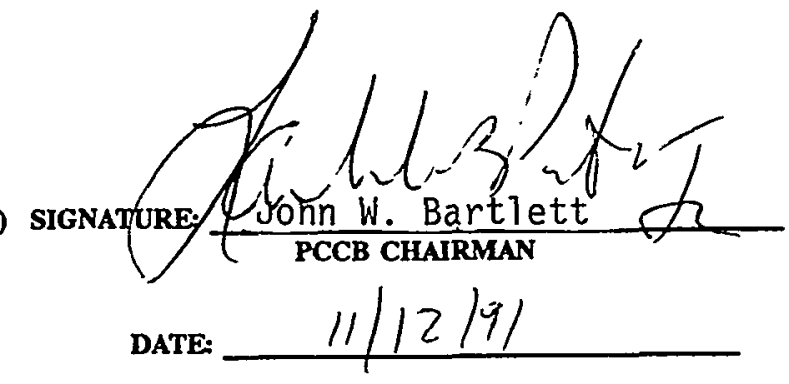

(10) IMPLEMENTATION COMPLETE:

VERIFICATION:

(IF REQUIRED) DIRECTOR, OQA

SIGNATURE:

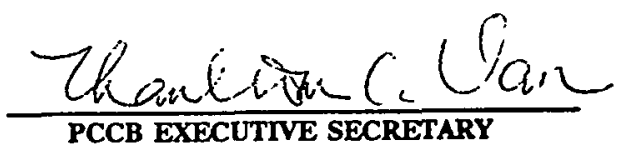

DATE: DATE: $\quad 2 / 5 / 4,2$ 


\section{DISCLAIMER}

This report was prepared as an account of work sponsored by an agency of the United States Government. Neither the United States Government nor any agency thereof, nor any of their employees, make any warranty, express or implied, or assumes any legal liability or responsibility for the accuracy, completeness, or usefulness of any information, apparatus, product, or process disclosed, or represents that its use would not infringe privately owned rights. Reference herein to any specific commercial product, process, or service by trade name, trademark, manufacturer, or otherwise does not necessarily constitute or imply its endorsement, recommendation, or favoring by the United States Government or any agency thereof. The views and opinions of authors expressed herein do not necessarily state or reflect those of the United States Government or any agency thereof. 


\section{DISCLAIMER}

Portions of this document may be illegible in electronic image products. Images are produced from the best available original document. 


\section{FOREWORD}

This Yucca Mountain Site Characterization Project (YMP) Plan meets the requirements of DOE Order 4700.1, as revised by DOE Notice 4700.4, SEN 27-90, and PR-23 memorandum dated 8/30/90, subject, "Baseline Change Control Process at the Executive Level." This Project Plan covers the period from the start of final Exploratory Studies Facility (ESF) Title II design through the submittal of the repository license application (LA) to the Nuclear Regulatory Commission (NRC).

This Project Plan addresses the surface and subsurface activities required to characterize the Yucca Mountain candidate site and provide data required for evaluation of suitability of the site for development of a high-level radioactive waste (HLW) and spent nuclear fuel repository. If the site is found to be suitable, the Office of Civilian Radioactive Waste Management (OCRWM) will develop, and the Secretary of Energy will submit, an LA to the NRC. The Project Plan does not address the follow-on activities for developing the repository, such as Final Procurement and Construction Design, obtaining construction authorization, or the construction of a potential repository. These activities will be addressed by a later Project Plan specific to the repository.

The YMP technical, cost, and schedule baselines and change control thresholds are summarized in Appendix D. Energy Systems Acquisition Advisory Board (ESAAB) (Level 0) baseline changes that exceed the Level 0 change control thresholds will be submitted to the ESAAB Baseline Change Control Board for approval.

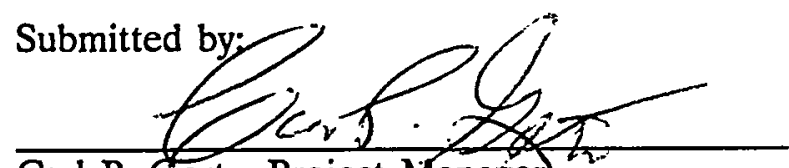

Carl P. Gertz, Project Manager

Yucca Mountain Site Characterization

Project Office

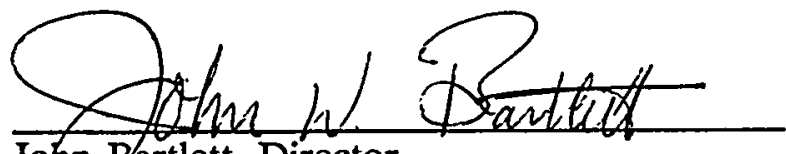

John Bartlett, Director

Office of Civilian Radioactive

Waste Management/Chairman,

Program Change Control Board

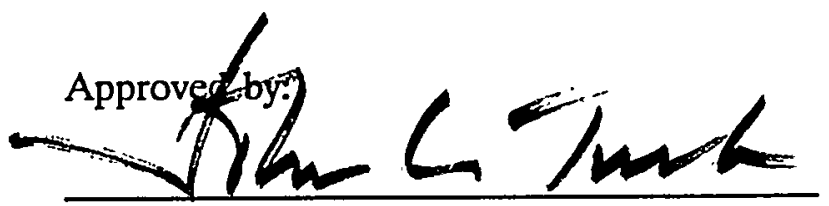

Acquisition Executive/Chairperson, Energy Systems Acquisition Advisory

Board
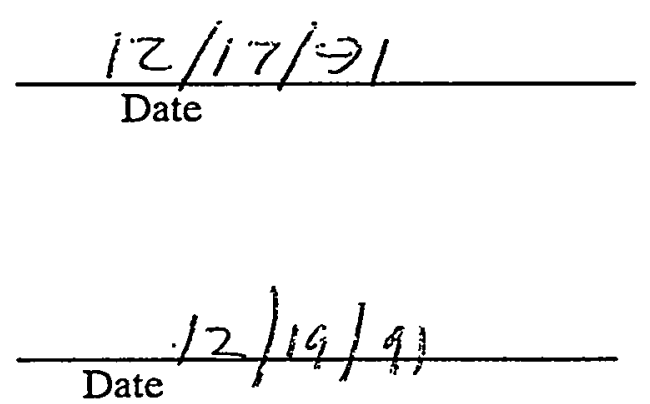

Date

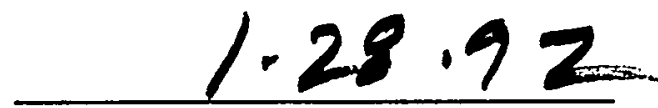

Date 


\title{
YUCCA MOUNTAIN SITE CHARACTERIZATION
}

\author{
PROJECT PLAN
}

1.0 INTRODUCTION $\ldots \ldots \ldots \ldots \ldots \ldots \ldots \ldots \ldots \ldots \ldots \ldots \ldots \ldots \ldots \ldots$ 1.1 YUCCA MOUNTAIN SITE CHARACTERIZATION PROJECT PLAN . . . . . . 1

2.0 MISSION NEED AND OBJECTIVES $\ldots \ldots \ldots \ldots \ldots \ldots \ldots \ldots \ldots \ldots \ldots \ldots$

2.1 PROGRAM MISSION $\ldots \ldots \ldots \ldots \ldots \ldots \ldots \ldots \ldots \ldots \ldots \ldots \ldots \ldots \ldots$

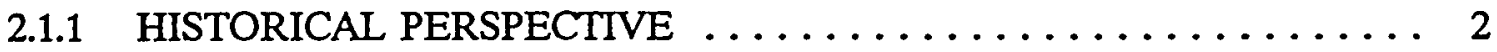

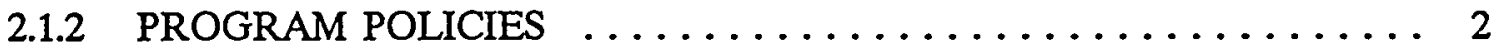

2.2 PROGRAM OBJECTIVES $\ldots \ldots \ldots \ldots \ldots \ldots \ldots \ldots \ldots \ldots \ldots \ldots \ldots \ldots$

2.3 YUCCA MOUNTAIN SITE CHARACTERIZATION PROJECT ROLE . . . . . . . 3

2.4 YUCCA MOUNTAIN SITE CHARACTERIZATION PROJECT OBJECTIVES $\ldots$

2.4 .1 TECHNICAL OBJECTIVES ...................... 4

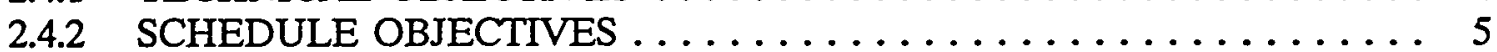

2.4 .3 QUALITY OBJECTIVES ..................... 6

2.4 .4 COST OBJECTIVES $\ldots \ldots \ldots \ldots \ldots \ldots \ldots \ldots \ldots \ldots \ldots \ldots \ldots \ldots \ldots \ldots \ldots \ldots$

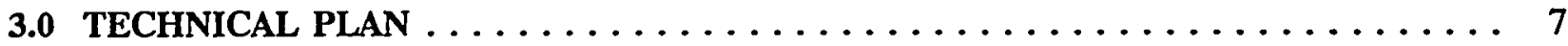

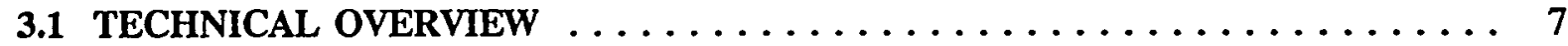

3.1 .1 OBTAIN ACCESS TO THE SITE $\ldots \ldots \ldots \ldots \ldots \ldots \ldots \ldots \ldots \ldots$

3.1.2 DEVELOP SITE PERFORMANCE ASSESSMENT METHODOLOGIES 7

3.1.3 PLAN AND CONDUCT SURFACE-BASED TESTING . . . . . . . . 7

3.1.4 PLAN AND CONSTRUCT THE EXPLORATORY STUDIES

FACILITY AND CONDUCT UNDERGROUND TESTING $\ldots \ldots \ldots \ldots \quad 8$

3.1.5 CONDUCT LABORATORY STUDIES AND DEVELOP SITE

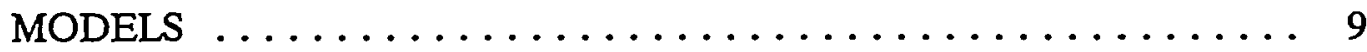

3.1.6 INTERACTION WITH EXTERNAL PARTIES $\ldots \ldots \ldots \ldots \ldots \ldots \ldots . . . \ldots$

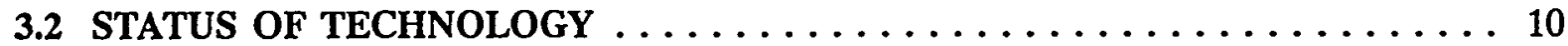

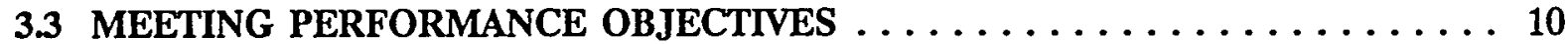

3.4 ALTERNATIVE DESIGNS/TECHNICAL APPROACHES $\ldots \ldots \ldots \ldots \ldots \ldots \ldots$

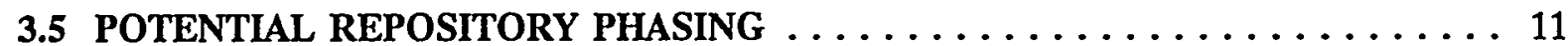

3.5.1 SITE CHARACTERIZATION PHASE . . . . . . . . . . . . 11

3.5.2 SITE SELECTION AND APPROVAL PHASE . . . . . . . . . . 13

3.6 WORK BREAKDOWN STRUCTURE $\ldots \ldots \ldots \ldots \ldots \ldots \ldots \ldots \ldots$

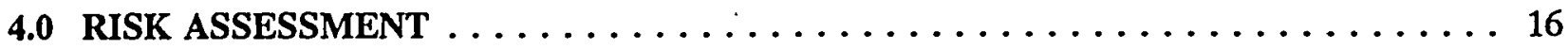

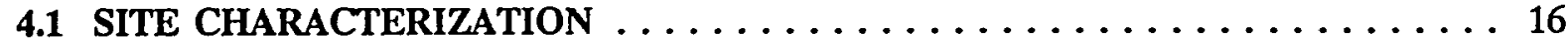

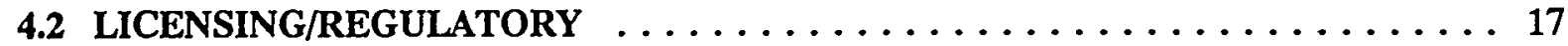

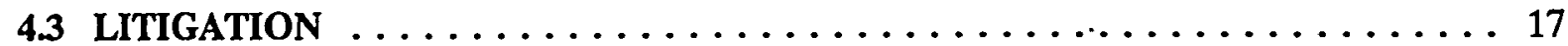

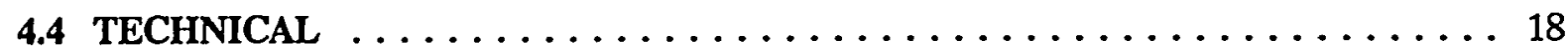

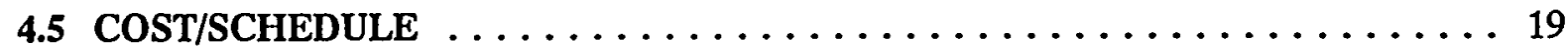

4.6 OFFICE OF CIVILIAN RADIOACTIVE WASTE MANAGEMENT OUTREACH EFFORTS ............................ 19

4.7 ENVIRONMENT . . . . . . . . . . . . . . . . . . 20

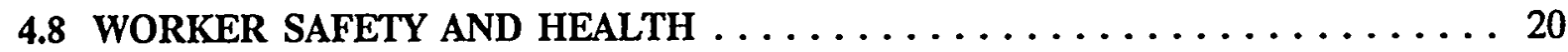




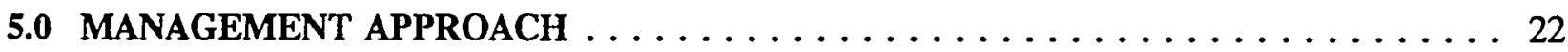

5.1 PROGRAM MANAGEMENT $\ldots \ldots \ldots \ldots \ldots \ldots \ldots \ldots \ldots \ldots \ldots . \ldots \ldots$

5.2 YUCCA MOUNTAIN SITE CHARACTERIZATION PROJECT MANAGEMENT . 22

5.3 ORGANIZATIONS AND RESPONSIBILITIES $\ldots \ldots \ldots \ldots \ldots \ldots \ldots .26$

5.3.1 PROGRAM RESPONSIBILITIES $\ldots \ldots \ldots \ldots \ldots \ldots \ldots \ldots \ldots 26$

5.3.2 YUCCA MOUNTAIN SITE CHARACTERIZATION PROJECT

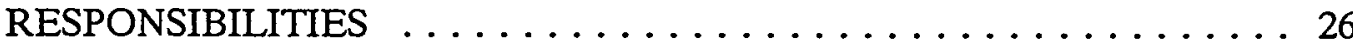

5.4 RELATIONSHIP WITH UTILITY INDUSTRY $\ldots \ldots \ldots \ldots \ldots \ldots \ldots \ldots 26$

5.5 YUCCA MOUNTAIN SITE CHARACTERIZATION PROJECT

MANAGEMENT CONTROL SYSTEMS $\ldots \ldots \ldots \ldots \ldots \ldots \ldots \ldots \ldots \ldots 29$

5.5 .1 MANAGEMENT INFORMATION $\ldots \ldots \ldots \ldots \ldots \ldots \ldots \ldots \ldots \ldots$

6.0 ACQUISITION STRATEGY $\ldots \ldots \ldots \ldots \ldots \ldots \ldots \ldots \ldots \ldots \ldots \ldots \ldots \ldots \ldots \ldots$

7.0 YUCCA MOUNTAIN SITE CHARACTERIZATION PROJECT SCHEDULE $\ldots \ldots 32$

8.0 RESOURCES PLAN $\ldots \ldots \ldots \ldots \ldots \ldots \ldots \ldots \ldots \ldots \ldots \ldots \ldots \ldots \ldots \ldots$

9.0 CONTROLLED ITEMS $\ldots \ldots \ldots \ldots \ldots \ldots \ldots \ldots \ldots \ldots \ldots \ldots \ldots \ldots$

10.0 SCHEDULED DECISION POINTS $\ldots \ldots \ldots \ldots \ldots \ldots \ldots \ldots \ldots \ldots \ldots \ldots \ldots \ldots \ldots \ldots \ldots$

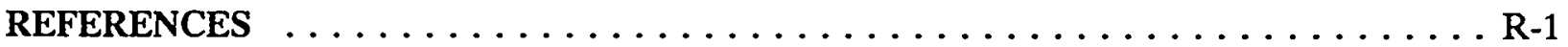

APPENDIX A: PROJECT CHARTER FOR THE YUCCA MOUNTAIN SITE

CHARACTERIZATION PROJECT $\ldots \ldots \ldots \ldots \ldots \ldots \ldots \ldots$ A 1

APPENDIX B: CONTRACTS AND AGREEMENTS $\ldots \ldots \ldots \ldots \ldots \ldots \ldots \ldots$ B-1

APPENDIX C: LIST OF ACRONYMS $\ldots \ldots \ldots \ldots \ldots \ldots \ldots \ldots \ldots \ldots \ldots$. 1

APPENDIX D: TECHNICAL, COST, AND SCHEDULE BASELINES AND CHANGE CONTROL THRESHOLDS $\ldots \ldots \ldots \ldots \ldots \ldots \ldots \ldots \ldots \ldots$ D-1

APPENDIX E: FUNDING AND MANPOWER REQUIREMENTS, FY83-FY92 . . . . . E E-1 


\section{YUCCA MOUNTAIN SITE CHARACTERIZATION \\ PROJECT PLAN}

\section{LIST OF FIGURES}

FIGURE TITLE

PAGE

3-1 YUCCA MOUNTAIN MINED GEOLOGIC DISPOSAL SYSTEM SUMMARY LOGIC DIAGRAM $\ldots \ldots \ldots \ldots \ldots \ldots 12$

3-2 MINED GEOLOGIC DISPOSAL SYSTEM WORK BREAKDOWN STRUCTURE . . . . . . . . . . 15

5-1a OFFICE OF CIVILIAN RADIOACTIVE WASTE MANAGEMENT ORGANIZATION ............. 23

5-1b OFFICE OF QUALITY ASSURANCE ORGANIZATION $\ldots \ldots 24$

5-1c ORGANIZATION OF THE OFFICE OF GEOLOGIC DISPOSAL ....................... 25

5-2 OFFICE OF CIVILIAN RADIOACTIVE WASTE MANAGEMENT COOPERATING OFFICES . ......... 27

5-3 ROLES OF YUCCA MOUNTAIN SITE CHARACTERIZATION PROJECT PARTICIPANTS ....... 28 


\subsection{INTRODUCTION}

The purpose of this document is to describe the Yucca Mountain Site Characterization Project (YMP) and establish an approved YMP baseline against which overall YMP progress and management effectiveness shall be measured. For the sake of brevity, this document will be referred to as the Project Plan throughout this document.

The Program Management System (PMS) Manual (DOE/RW-0043) defines the Project Plan as a Program-level controlled document that is submitted through the Director, Office of Civilian Radioactive Waste Management (OCRWM), to the Acquisition Executive for approval. Initial issuance and changes to the Project Plan will be controlled by the Program Change Control Board with copies of all page changes forwarded to the ESAAB Secretariat for information purposes. The Project Plan complies with DOE Order 4700.1 as revised by DOE Notice 4700.4 and SEN-27-90.

\subsection{YUCCA MOUNTAIN SITE CHARACTERIZATION PROJECT PLAN}

This Project Plan only addresses activities up to the submittal of the repository license application (LA) to the Nuclear Regulatory Commission (NRC). A new Project Plan will be submitted to establish the technical, cost, and schedule baselines for the final design and construction phase of development extending through the start of repository operations, assuming that the site is determined to be suitable.

The Project Charter, which is part of the Project Plan (Appendix A), delineates management responsibility, authority, and accountability of the Yucca Mountain Site Characterization Project Office (YMPO) along with operational management relationships with the OCRWM, other departmental elements, and external organizations. 


\subsection{MISSION NEED AND OBJECTIVES}

\subsection{PROGRAM MISSION}

The policy framework for the ultimate disposal of the nation's spent nuclear fuel and highlevel waste (HLW) was defined by Congress in the Nuclear Waste Policy Act of 1982, as amended (NWPA). The NWPA established subsurface storage of spent nuclear fuel and HLW in geologic repositories as the preferred method of long-term disposal. The NWPA established the OCRWM within the DOE and directed it to proceed with the selection of potential sites for geologic repositories.

The mission of the OCRWM is to dispose of this nation's spent fuel and HLW in a manner that protects the health and safety of workers and the public and the quality of the environment. Although embodied in the Federal repository program that was initiated in 1976, this mission was explicitly established by the NWPA as originally enacted and reaffirmed by the 1987 amendments to the NWPA.

\subsubsection{HISTORICAL PERSPECTIVE}

In May 1986, in accordance with the terms of the NWPA, the President designated three sites for site characterization as a necessary prerequisite for selection of a site for the first repository. One of the designated sites was the Yucca Mountain site. The 1987 amendments to the NWPA designated the Yucca Mountain site as the sole site to be characterized. The work that had been ongoing was incorporated into a project organization, formerly designated as the Nevada Nuclear Waste Storage Investigation Project, and subsequently redesignated the Yucca Mountain Project in 1988. In 1990, the Yucca Mountain Project was renamed the Yucca Mountain Site Characterization Project.

\subsubsection{PROGRAM POLICIES}

The following overall policies guide the formulation and implementation of the OCRWM Program:

1. The protection of public health and safety, worker health and safety, and the quality of the environment are of paramount importance.

2. The program must be credible by virtue of its integrity and technical excellence and directed at reaching consensus in the scientific community.

3. The program must provide timely and reliable information to the public and ensure appropriate opportunities for participation by the public.

4. The program must be conducted in a financially responsible and cost-effective manner and on the basis of full cost recovery. 


\subsection{PROGRAM OBJECTIVES}

The following specific program objectives for the Mined Geologic Disposal System (MGDS) were established in the OCRWM's Multiyear Program Plan dated December 14, 1990:

1. Timely disposal: to establish as soon as practicable (i.e., by the year 2010) the ability to safely dispose of spent nuclear fuel and defense high-level waste in a potential geologic repository licensed by the NRC.

2. Timely and adequate waste acceptance: to begin the operation of the waste-management system as soon as practicable (i.e., in 1998) by beginning to accept waste at a monitored retrievable storage (MRS) facility.

3. Program confidence: to establish confidence in program actions and plans such that the management of radioactive waste is not an obstacle to the nuclear energy option.

4. System flexibility: to ensure that the program has the flexibility necessary for adapting to future circumstances while fulfilling established commitments.

\subsection{YUCCA MOUNTAIN SITE CHARACTERIZATION PROJECT ROLE}

The role of the YMP in supporting the overall mission of the program shall be to characterize the Yucca Mountain candidate site to determine its suitability for use as a potential geologic repository.

\subsection{YUCCA MOUNTAIN SITE CHARACTERIZATION PROJECT OBJECTIVES}

One of the OCRWM's strategic objectives is to determine, as soon as practicable, whether the Yucca Mountain site is suitable for development as a potential repository. The OCRWM's approach is to perform a comprehensive site characterization program, including a prioritized series of surface-based and underground tests designed to detect, at the earliest stage practicable, conditions that would indicate that the site is unsuitable. The OCRWM will focus on the following sub-objectives during the next six years:

- Obtain access to the site

- Develop site evaluation methodologies

- Plan and conduct laboratory studies, modeling, and performance assessments

- Plan and conduct surface-based testing 
- Plan, design, and construct the Exploratory Studies Facility (ESF) and conduct underground testing

- Interface with other OCRWM Program elements (e.g., MRS and Transportation)

- Interact with external parties (e.g., Nuclear Regulatory Commission (NRC), Nuclear Waste Technical Review Board (NWTRB), Nevada)

In parallel with these activities, the primary focus of the design activities, in addition to the ESF, will be on those repository and waste package design activities necessary to support (1) the site characterization test program or resolution of concerns about site suitability, and (2) definition and analyses of the interface between the ESF and the repository.

\subsubsection{TECHNICAL OBJECTIVES}

Three sections of the Code of Federal Regulations (CFR) provide the upper-level Federal requirements that the OCRWM must incorporate into the development of a repository:

1. 10 CFR Part 60 issued by the NRC

2. 10 CFR Part 960 issued by DOE

3. 40 CFR Part 191 issued by the U.S. Environmental Protection Agency (EPA).

These regulations outline the upper-level regulatory requirements and performance objectives for the siting, development, licensing, construction, operation, and closure of a geologic repositcry and are mandatory for all phases of the YMP. Both the NWPA and the underlying regulations incorporate by reference additional federal laws and regulations that are applicable to the development of a potential repository. For example, the NWPA requires application of the National Environmental Policy Act of 1969 (NEPA), which in turn requires preparation of an Environmental Impact Statement (EIS) during the course of this program. The generic requirements for the potential repository are specified in the Waste Management System Requirements (WMSR) Volume I (DOE/RW-0264).

A set of technical objectives has been developed that will support a determination of site suitability or unsuitability. The technical objectives of the YMP, which span geologic, hydrologic, geochemical, geophysical, metallurgical, engineering, radiological, transportation, environmental, and socioeconomic disciplines, are as follows:

1. Determine overall site suitability or unsuitability of the Yucca Mountain site for permanent high-level radioactive waste and spent nuclear fuel storage considering radiological and nonradiological safety, environmental protection, and technical feasibility.

2. Prepare designs for the MGDS at Yucca Mountain that are adequate to support a license application to the NRC. 
3. Develop the analytical methods and models required to perform the evaluations that support demonstrations of preclosure and postclosure performance.

4. Develop plans, schedules, and cost estimates for reference and alternative waste package and repository designs so the relative cost and effectiveness can be determined.

5. Collect site characterization data and information sufficient to provide the information required by repository and waste package design and to establish preclosure and postclosure performance.

6. Demonstrate whether an MGDS at Yucca Mountain can be sited, constructed, operated, closed, and decommissioned and that the associated transportation system can be sited, constructed, and operated so that the quality of the environment will be protected and there will be no unacceptable risks to worker and public health and safety.

The technical objectives [from the regulations] were consolidated at the summary level, in August 1987, into an Issues Hierarchy for an MGDS (DOE/RW-0101), which also lists the major issues and their subsidiary design and performance issues. This document was used as a framework in the development of the Site Characterization Plan (SCP) (DOE/RW-0199) issued in final form in December 1988.

At a more detailed level, the technical objectives for the site characterization activities have been specified in Chapter 8 of the SCP. That Chapter contains matrices correlating technical activities to the applicable regulations, issues hierarchy, and goals obtained through performance allocation.

The technical baseline is outlined in the document hierarchies presented in the Program Management System (PMS) Manual for the OCRWM and the Project Management Plan (PMP) (YMP/88-2) for the YMP. This technical baseline hierarchy is also described in Appendix D. For design purposes, a set of requirements documents is employed to generate the design basis for each major activity. For the repository, technical baseline requirements are in Waste Management Systems Requirements (WMSR) Vol. I (DOE/RW-0264) and WMSR Vol. IV (DOE/RW-0268). These documents give guidance on the content of the YMP's MGDS Design Requirements and MGDS Description documents.

\subsubsection{SCHEDULE OBJECTIVES}

The Project schedule baseline is referenced in Section 7. This schedule baseline includes: Acquisition Executive (Level 0), Program (Level 1), and Project (Level 2) milestones, as well as key decision points requiring Energy Systems Acquisition Advisory Board (ESAAB) approval, and annual Energy Systems Acquisition Reviews (ESARs). The major phases of the YMP are contained in Section 3.5 of this plan. 


\subsubsection{QUALITY OBJECTIVES}

The overall quality objective of the program is to achieve and sustain a high level of quality in all YMP activities. The achievement of quality is the responsibility of line management and line technical staff. The verification of quality is the responsibility of the Quality Assurance (QA) organization.

Activities affecting radiological safety or waste isolation are subject to the QA requirements of the NRC and shall be conducted in accordance with a formal QA program that is in compliance with the OCRWM's Quality Assurance Requirements Document (DOE/RW-0214) and Quality Assurance Program Description (QAPD) Document (DOE/RW-0215).

\subsubsection{COST OBJECTIVES}

Funding for the YMP is provided by the Nuclear Waste Fund, which was established by the Nuclear Waste Policy Act (NWPA). The cost baseline hierarchy is shown in Appendix D. 


\subsection{TECHNICAL PLAN}

\subsection{TECHNICAL OVERVIEW}

An explanation of the YMP's objectives up to the time of LA is presented in the following sections.

\subsubsection{OBTAIN ACCESS TO THE SITE}

The OCRWM's immediate priority is to obtain the remaining permits or otherwise gain unrestricted access to the site for comprehensive surface-disturbing work. The State of Nevada and DOE are involved in litigation over the permits. On June 12, 1991, and July 17, 1991, respectively, the State of Nevada issued two of the three pending environmental permits, an air quality permit, and an underground injection control permit. With these permits, YMP began limited new surface-based testing at the site - Midway Valley trenching and calcite-silica testing - on July 8, 1991. Full-scale surface-based testing can now begin, except for tests involving the pumping of water.

To preclude prolonged legal battles with the State over future permit applications, the Administration included a legisative initiative as part of the proposed National Energy Strategy legislation, which, in brief, would transfer permitting authority from the State to the Federal government.

\subsubsection{DEVELOP SITE PERFORMANCE ASSESSMENT METHODOLOGIES}

The OCRWM is continuing to develop models for assessing the performance of both natural and engineered barriers of the repository system and establishing compliance with applicable regulations. This is an iterative process; models will become more refined as data are gathered and the waste isolation system is better understood.

\subsubsection{PLAN AND CONDUCT SURFACE-BASED TESTING}

The focus of the surface-based testing program is to complete the data collection activities described in the Site Characterization Plan (SCP). The primary activities in preparation for surface-based testing are the following:

- Completion of a testing prioritization study. This study will establish priorities for surface-based and underground (i.e., in the ESF) data collection activities. This study will also provide a systematic approach for evaluating the importance of the tests performed during site characterization. 
- Integration, implementation, and verification of test and QA controls with study plans and procedures to ensure no significant adverse impacts occur to the site during characterization that would cause the site to be unsuitable.

- Drilling of prototype boreholes in the Yucca Mountain area to prove dry drilling and coring concepts for later use at Yucca Mountain.

The surface-based testing program has been gathering data and will continue to gather data on a variety of geologic, meteorologic, hydrologic, geochemical, seismic, and other conditions at the site. For example, seismic monitoring and volcanic studies in the Yucca Mountain region are being conducted to assess the recurrence interval and magnitude of events that could affect waste isolation at the site in the future.

The OCRWM began to develop recommendations on prioritizing surface-based testing in February, 1990. Recently, the scope of that effort has been revised, as the Testing Prioritization Task (TPT), to consider all tests enumerated in the SCP. Potential adverse conditions based on the DOE's Siting Guidelines (10 CFR Part 960) and NRC's Siting Criteria (10 CFR 60.122) are the basis for determining which site conditions should be investigated early and, in addition, which testing activities are most likely to detect and/or characterize these conditions.

The development of an iterative site suitability evaluation is now ongoing by the YMP. The methodology and evaluation are intended to provide an early and subsequent periodic interim evaluations of site suitability. Although these evaluations are still in progress, it is likely that the surface-based tests discussed below will be initiated early in the site characterization program.

The YMP has excavated trenches to collect information on recent faulting and the potential for earthquakes and surface-fault offsets in the vicinity of the proposed surface facilities. Additional trenches have been excavated to help understand the origin of calcite-silica deposits at the site. The NRC has formally accepted the QA programs for this work. In addition, once all the needed permits are received, the YMP will begin on-site drilling, first to confirm that the prototype dry drilling and coring methods and other procedures can be applied to the site, and then to collect the information called for in the SCP, including information on geology, hydrology, geochemistry, volcanism, and tectonics.

\subsubsection{PLAN AND CONSTRUCT THE EXPLORATORY STUDIES FACILITY AND CONDUCT UNDERGROUND TESTING}

Although the OCRWM will focus near-term activities on surface-based testing, it also will construct an underground test facility as part of the site characterization program. The OCRWM has completed an ESF Alternatives Study, which provided the basis for establishing a preferred configuration and construction method. In response to suggestions by the NRC and the Nuclear Waste Technical Review Board (NWTRB), the methods analyzed for possible use in excavating the ESF were expanded to consider the use of mechanical tunneling equipment.

The Calico Hills stratigraphic unit is an important natural barrier between the repository horizon and the underlying groundwater table. The NRC staff was concerned that 
plans for excavation and testing in the Calico Hills unit were not based on an analysis of the risks and benefits of alternative methods for obtaining the needed information. Their concern, cited in their review of the Consultation Draft of the SCP, was resolved on the basis that the OCRWM would perform this risk/benefit analysis and that the NRC would be consulted before the results of the analysis are implemented. The results of the Calico Hills risk/benefit analysis have been published by the YMP and have been integrated into the study of alternative ESF configurations. ESF design studies are proceeding in accordance with guidance provided by the OCRWM Director on the basis of the results from the ESF Alternatives Study, which recommended two ramps be used for access to the underground rather than two shafts. Extensive drifting is planned in both the Topopah Spring and Calico Hills rock units to allow extensive underground in situ testing to occur for assessing the suitability of the site. Title I design of the ESF is being revised. Title II design will begin upon direction from the OCRWM Director, following ESAAB approval of KD-2.

\subsubsection{CONDUCT LABORATORY STUDIES AND DEVELOP SITE MODELS}

In addition to planned surface-based and ESF testing, laboratory testing in geology, hydrology, and geochemistry is ongoing. The focus of these investigations will be the composition, thermal and mechanical properties, and hydrologic properties of samples from Yucca Mountain, as well as the chemistry of groundwater from both the unsaturated zone and the saturated zone. Other laboratory studies will examine the geochemical behavior of the site with respect to radionuclide transport processes.

Site model development will continue in the areas of rock characteristics; unsaturated-zone, saturated-zone, and regional groundwater flow systems; groundwater geochemistry; the behavior of the site in the waste package environment; and the regional and global climates. These models will describe and predict behavior of these natural systems as regards the site.

\subsubsection{INTERACTION WITH EXTERNAL PARTIES}

In parallel with its technical activities, the YMP will continue to conduct an active external relations program in Nevada, including support to existing public information offices in Las Vegas and Beatty and a future office in Nye County; an expanded Speakers Bureau (currently giving more than 100 presentations per year); and an expanded site tour program that focuses on new field work.

The OCRWM recognizes that independent technical oversight of the program is critical to building credibility and support. A major priority of the program will, therefore, be to support interactions with parties, external to the DOE, including the NRC, State of Nevada and affected local governments, NWTRB, and Advisory Committee on Nuclear Waste. In addition, reviews of the program have been conducted by the electric utilities, General Accounting Office, DOE Inspectors General's Office, and the National Academy of Sciences through its Board on Radioactive Waste Management. Relationships and interactions between 
OCRWM and these parties external to DOE are described in detail in Appendix A of this document, "Project Charter for the Yucca Mountain Site Characterization Project".

\subsection{STATUS OF TECHNOLOGY}

The disposal of radioactive waste in a geologic repository will depend upon the use of multiple barriers to protect the health and safety of the public for thousands of years. These barriers consist of seals for shafts, ramps and boreholes, engineered barriers, and the natural barriers provided by the geologic formation in which the repository is located. The technology for handling radioactive waste in a safe manner has been developed to the point where the processes for receiving, processing, emplacing, and retrieving the waste can be accomplished within the regulatory requirements for the control of release of radioactivity during the preclosure period.

However, the time frame involved in the disposal of the radioactive waste is far greater than that which has been encountered in the engineering experience of mankind. The difficulties associated with the assessment of the design and performance of the repository over such long periods have been recognized in the promulgation of the applicable regulations.

The SCP provides a detailed description of the information already obtained on the candidate site and additional data required for characterization. The Issues Hierarchy (DOE/RW-0101) was used to develop the information needs and plans for obtaining this information during the site characterization phase.

Equipment and techniques for deep dry drilling and coring for exploration are being investigated. However, the repository is expected to be designed, constructed, and operated based upon existing technology. For the waste packages, on the other hand, some development work is required to advance the state-of-the-art, especially in the areas of materials science and engineering. Advances are needed to allow reliable prediction of the service life of container materials and rates of release of radionuclides from waste forms under postclosure repository conditions.

\subsection{MEETING PERFORMANCE OBJECTIVES}

The overall performance requirements of the MGDS as specified in the WMSR (Vols. I and IV) are intended to ensure that the performance of a potential geologic repository, including the geologic setting, the engineered barrier system, ramps, and shafts, boreholes, and their seals, shall function as a system to meet the EPA postclosure radionuclide release limits. The performance of the total MGDS is ultimately dependent on the performance of each of the subsystems, including the site subsystem; the engineered barrier subsystem, including the waste package; and the shaft and borehole seals.

The designs for a Yucca Mountain MGDS must be adequate to support a license application to the NRC. The traditional Title I and Title II designs are represented by the License Application Design (LAD) and the Final Procurement and Construction Design, 
respectively. Design requirements resulting from detailed safety and reliability analyses will be integrated into the LAD and will form the basis for information required in the Safety Analysis Report as part of the LA to the NRC. The performance objectives, as specified in 10 CFR Part 60 and other Federal regulations, flow down into the requirements documents needed for design of the ESF, repository, and waste package.

\subsection{ALTERNATIVE DESIGNS/TECHNICAL APPROACHES}

As a result of a number of concerns expressed by the NWTRB and the NRC (in the Site Characterization Analysis), additional evaluations of alternative ESF designs, repository development strategies, and waste package configurations and strategies are currently being considered. The results of these analyses will be reflected in revisions to the Technical Baseline. The YMP baseline shall be maintained to be consistent with the program baseline. Consideration of alternative designs will continue as the site characterization data become available, and the design of the potential repository evolves.

In addition to the consideration of ESF design alternatives, the OCRWM is prioritizing the surface-based characterization activities to allow for early identification of potentially disqualifying conditions.

\subsection{POTENTIAL REPOSITORY PHASING}

Potential-repository development can be divided into the following phases: site characterization, site selection and approval, licensing review, construction, operation (including retrieval, if necessary), closure, license termination, and decommissioning. These phases are not necessarily sequential and, in some cases, overlap. This plan currently covers YMP activities only for the site characterization, and site selection and approval phases. Figure 3-1 depicts activities during these two phases leading up to submittal of a license application to the NRC. Activities for licensing review and construction phases will be addressed in a later Project Plan.

\subsubsection{SITE CHARACTERIZATION PHASE}

The site characterization phase extends through a determination as to whether or not the site is suitable, and if found suitable, through Presidential recommendation of the site to Congress for development as a repository. If found not to be suitable, the following provisions of Section 113(c) of the NWPA apply:

"(3) If the Secretary at any time determines the Yucca Mountain site to be unsuitable for development as a repository, the Secretary shall--

"(A) terminate all site characterization activities at such site;

"(B) notify the Congress, the Governor and legislature of Nevada of such termination and the reasons for such termination; 


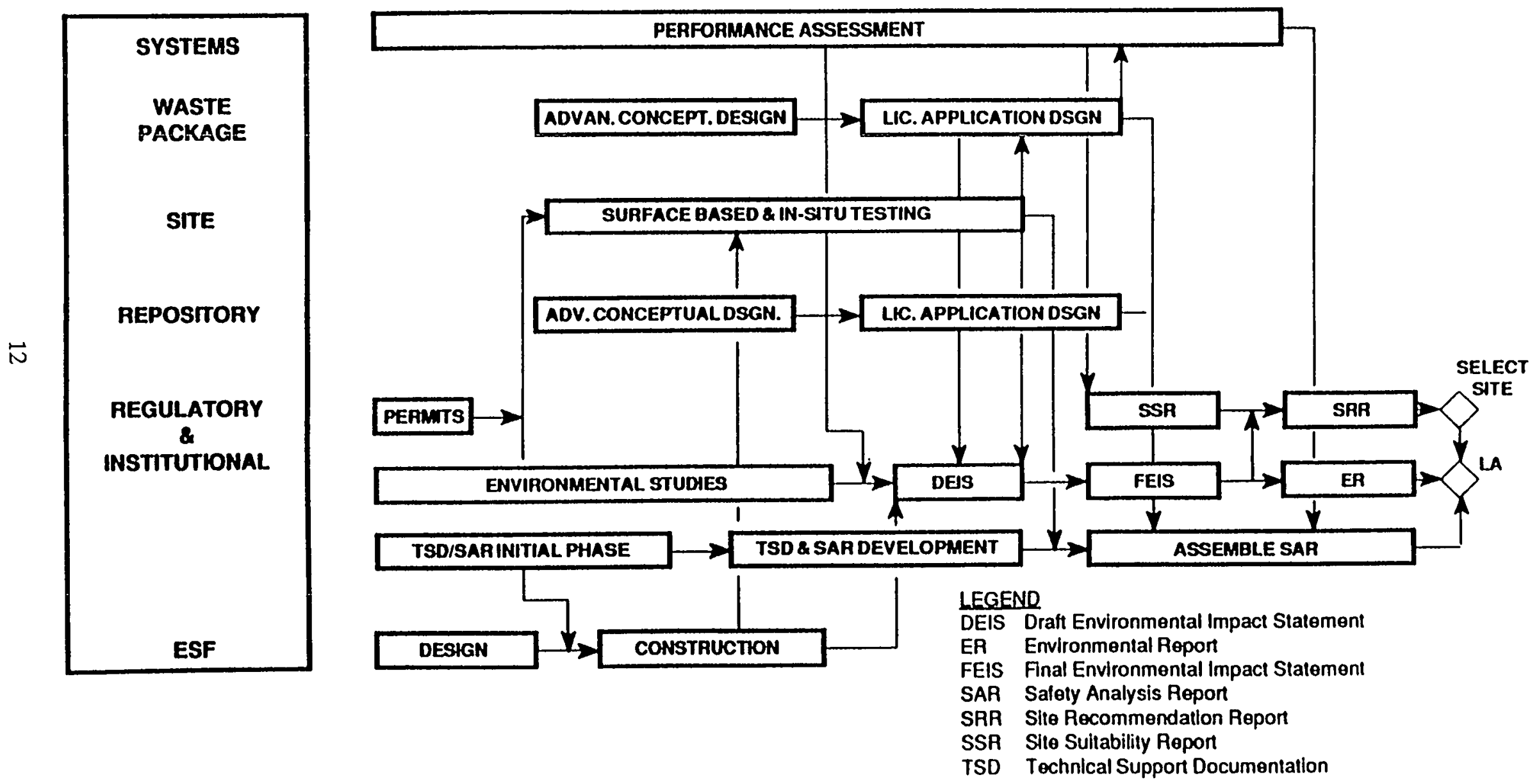

Figure 3-1. Yucca Mountain MGDS Summary Logic Diagram 
"(C) remove any high-level radioactive waste, spent nuclear fuel, or other radioactive materials at or in such site as promptly as practicable;

"(D) take reasonable and necessary steps to reclaim the site and to mitigate any significant adverse environmental impacts caused by site characterization activities at such site;

"(E) suspend all future benefits payments under subtitle $F$ with respect to such site; and

"(F) report to Congress not later than 6 months after such determination the Secretary's recommendations for further action to assure the safe, permanent disposal of spent nuclear fuel and high-level radioactive waste, including the need for new legislative authority."

The primary emphasis of the site characterization phase will be to determine whether the Yucca Mountain site will be suitable and licensable as a potential geologic repository site in accordance with the guidelines of 10 CFR Part 960 and the NRC regulations of 10 CFR Part 60 . The site characterization phase includes conducting various scientific investigations, including surface-based, subsurface, and laboratory activities. These investigations will be used to determine the characteristics of the site to support evaluations of site suitability; perform performance assessments; design the potential repository, seals for shafts and boreholes, and engineered barriers; support an Environmental Impact Statement (EIS); and support preparation of a license application. (The EIS will be prepared in accordance with the NEPA and NWPA as amended.) As information is gathered and design choices are considered, performance assessments will be conducted to determine the impact of new information on the projected performance of the site and repository.

Preliminary conceptual designs of the ESF, repository, and waste package were prepared in support of the Environmental Assessment (EA) and the Site Characterization Plan. WMSR Vols. I and IV and the WMSD define the Program-level technical baseline. The YMP is responsible for developing the YMP-level technical baseline in accordance with the YMP configuration management process. That technical baseline will be used to control the design process for the ESF and the site characterization activities.

The YMP shall implement appropriate management processes and QA plans and procedures to ensure that the information obtained during the site characterization phase and subsequent phases will be useful in the licensing process.

\subsubsection{SITE SELECTION AND APPROVAL PHASE}

The site selection and approval phase extends from the Presidential recommendation to Congress to submittal of the LA to the NRC. If the site is found suitable for repository development, the OCRWM will prepare a Site Recommendation Report and an EIS for submission by the Secretary to the President for selection of the Yucca Mountain site for the first repository. The Secretary of Energy will transmit the report and the accompanying EIS to the President. If the President approves the recommendation and the site designation becomes effective, the LA will be submitted to the NRC for review. 


\subsection{WORK BREAKDOWN STRUCTURE}

The Work Breakdown Structure (WBS) provides an orderly framework for planning and controlling the work to be performed in achieving the objectives of the program and for summarizing data. The Program WBS is contained in the PMS Manual (DOE/RW-0043). The WBS for the MGDS is shown in Figure 3-2 of this Project Plan. Descriptions of the YMP's individual WBS elements can be found in the WBS Dictionary (YMP/CC-0001). 


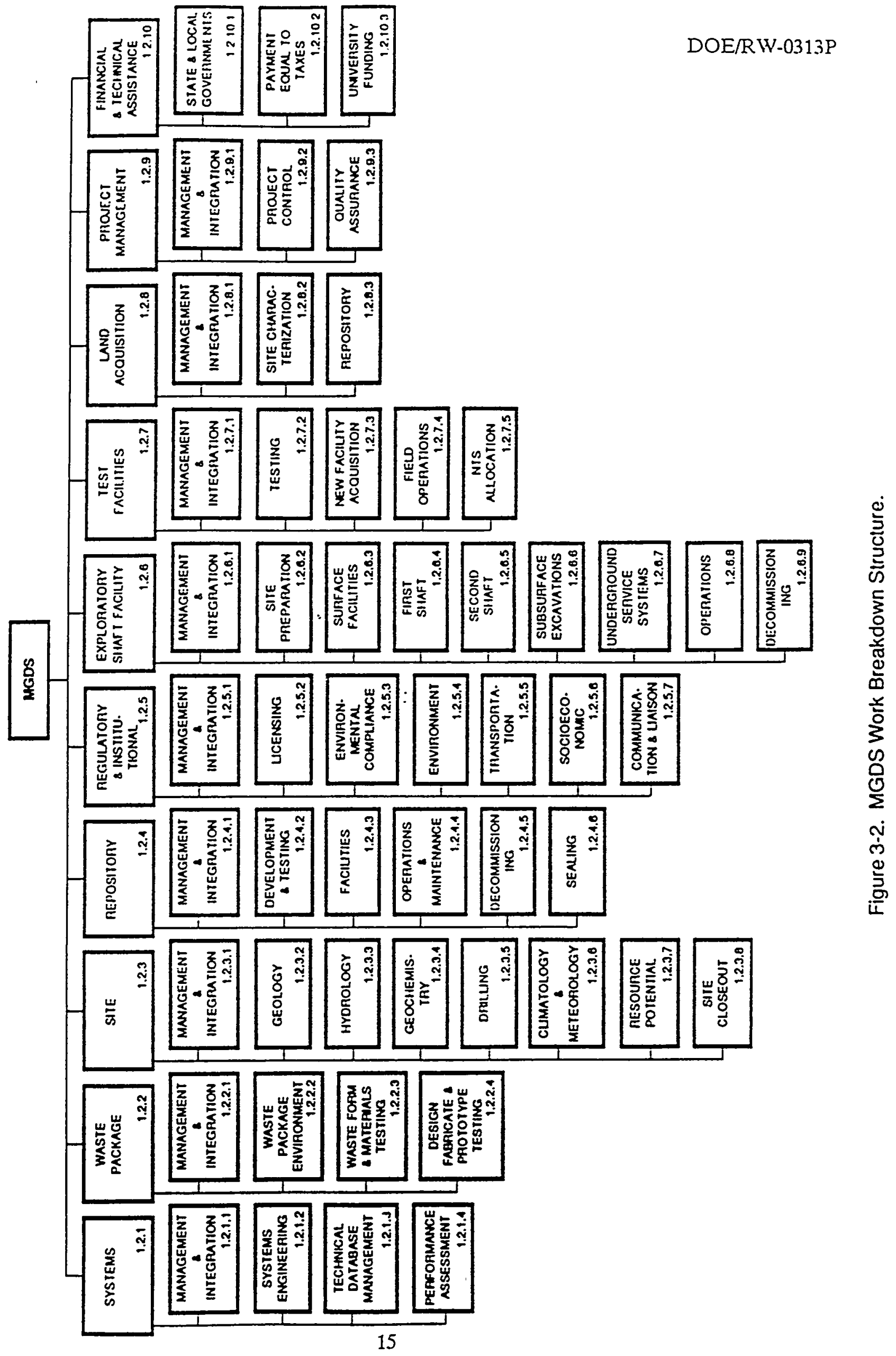




\subsection{RISK ASSESSMENT}

As a part of the effort to evaluate the suitability of Yucca Mountain for an MGDS, the OCRWM must address the following major issues: (1) the site's long-term intrinsic capability to isolate waste from the environment; (2) the ability of the site and waste package to meet the performance requirements outlined in $10 \mathrm{CFR}$ Part 60; and (3) the acceptability of the social and environmental impacts of a repository.

The NWPA and implementing regulations specify the requirements and performance objectives that must be satisfied in order to provide reasonable assurance that a geologic repository can be designed, constructed, licensed, operated, and permanently closed, within acceptable limits of risks to the health and safety of the worker and the public, and to the environment. Factors that impact the ability of the YMP to meet these requirements and performance objectives need to be identified, the uncertainties associated with these factors assessed, and mitigating actions evaluated by program and YMP management. The program is designed to moderate the impact of such factors.

A number of issues must be resolved concerning the evaluation of the site's capability to provide long-term isolation and to meet the performance objectives. To support preparation of the SCP, these issues were summarized in the Issues Hierarchy (DOE/RW-0101).

There are a number of factors that present some level of uncertainty to the DOE's ability to resolve the issues. Identified risks and potential impacts are described below. Risk management strategies will be developed by managers to minimize potential technical, cost, and schedule impacts.

\subsection{SITE CHARACTERIZATION}

A degree of uncertainty exists that, during site characterization, conditions will be encountered that will indicate that the site is unsuitable for repository development. The disqualifying conditions specified in accordance with 10 CFR Part 960 will be the basis for the site suitability analysis. The site characterization program has been structured to investigate the existence of potentially disqualifying conditions early in the site investigation phase so that program resources are conserved as much as possible. Studies conducted to date on the geology, hydrology, geomechanics, geochemistry, seismic, tectonic, and volcanic history of the region have not found conditions indicating that the site is unsuitable.

Risk Level. The results of activities that have been conducted to date in the selection of the Yucca Mountain site for characterization (i.e., the current knowledge of the site conditions) indicate that the likelihood of finding a condition that would make the site unsuitable is low as described in the reports published by the YMP about the Testing Prioritization Task (TPT) and Calico Hills/Risk Benefit Analysis. 


\subsection{LICENSING/REGULATORY}

Delays may be encountered leading up to the LA if information provided by DOE were found by the NRC to be insufficient in quality or quantity during the prelicensing consultations. This may necessitate collection of additional data and performance of related technical evaluations prior to the LA.

The NRC regulations (10 CFR Part 60) require that the NRC must have reasonable assurance in order to make its findings. The DOE must supply sufficient data, analyses, and logical arguments to support these findings, thereby reducing the likelihood of delay in the licensing process.

Program management has been extensively involved in detailed planning and design phases to mitigate risks. The DOE is investigating alternate licensing strategies for demonstrating compliance with the NRC requirements and pursuing interactions with the NRC and EPA in an effort to avoid delays. Program management is also developing and implementing a QA program, subject to NRC review and approval, that will ensure adequate control on activities supporting licensing.

The U.S. Court of Appeals for the First Circuit has vacated and remanded to the EPA for further proceedings the Environmental Standards for the Disposal of Spent Fuel, High-Level Waste, and Transuranic Waste (Subpart B of 40 CFR Part 191). The basic information needed to demonstrate compliance with any disposal standard eventually promulgated by EPA could change from the remanded version on which site characterization plans have been based (i.e., the version of 40 CFR Part 191 published on September 19, 1985). Changes that may be made by the EPA to its standards will be evaluated by the DOE and its programs will be revised as appropriate. However, there is a possibility of significant delay resulting from changes to 40 CFR Part 191.

Risk Level. The likelihood that there will be significant slips in the schedule due to insufficient or inadequate information or program changes resulting from revisions to $40 \mathrm{CFR}$ Part 191 is considered to be at a high level. In the extreme, the NRC may not docket the LA unless the uncertainties regarding technical issues are reduced to an acceptable level.

\subsection{LITIGATION}

Considerable difficulty has been encountered in receiving the required State of Nevada permits for the start of new surface-disturbing activities. Both DOE and the State of Nevada chose to file lawsuits raising various legal points. On November 1, 1989, the Nevada Attorney General issued an opinion that the State of Nevada had disapproved the site within the meaning of Section 115 of the NWPA. On January 5, 1990, the State of Nevada filed a petition with the U.S. Court of Appeals for the Ninth Circuit seeking a declaration that actions of the Nevada State legislature constitute notice of disapproval under Section 116(b)(1) of the NWPA and that Yucca Mountain is unsuitable for site characterization. On January 25, 1990, the United States Attorney General filed suit in the U.S. District Court for the District of Nevada for a declaration that the State of Nevada has not submitted a valid notice of disapproval under the NWPA and an order that the State act upon the DOE's permit 
applications. On September 19, 1990, the U.S. Court of Appeals for the Ninth Circuit ruled that the State of Nevada's Notice of Disapproval is ineffective under the NWPA. Subsequently on March 4, 1991, the Supreme Court denied a petition by the State of Nevada to review the decision of the Ninth Circuit.

To preclude prolonged legal battles with the State over future permit applications, the Administration included a legislative initiative as part of the proposed National Energy Strategy which would transfer permitting authority from the State to the Federal Government.

The DOE also recognizes the likelihood of additional litigation as work progresses through site suitability determination, EIS issuance, and preparation of an LA.

There is also the risk of further schedule delay if the site is recommended for a repository by the President and the State files a notice of disapproval. Litigation is highly likely if Congress then overrides the State and passes a resolution of siting approval.

Risk Level. The potential for litigation represents a high risk in terms of additional YMP delay or in preventing schedule improvements and may substantially increase YMP cost; the risk level for YMP discontinuance as a result of such factors is indeterminate.

\subsection{TECHNICAL}

A major technical risk is that results of performance assessments will not provide the necessary assurance that the requirements of the NRC and EPA regulations can be met based upon the available scientific and engineering data. Another risk is the possible inability to acquire adequate knowledge and understanding of the processes acting to disrupt the site (especially the magnitude and recurrence intervals of disruptive events). Should this happen, uncertainty about the waste isolation potential of Yucca Mountain could remain too high to be acceptable. The failure of the performance assessments to support a finding of compliance with regulatory requirements could not only lead to increases in cost and schedule delays, but, in the limit, could result in the inability to license the repository. The risk to the project of this condition is not assessable until site characterization has been completed.

The technical uncertainty in the prediction of long-term materials behavior is considered to be high. This risk, however, is currently addressed by employing design flexibility and container material alternatives. There is also uncertainty regarding the outcome of corrosion testing of the waste container materials under representative conditions or tests of the host rock's response to thermal loading. Unexpected test results may require significant changes in the design of the repository or waste package. In addition, other technical uncertainties arise from the unprecedented service life requirements for the waste package. The prediction of performance of this engineered system for hundreds to thousands of years requires an understanding of materials degradation processes that is sufficient to permit the modeling of waste package behavior and to allow extrapolation of this behavior over large time periods for the expected range of repository environmental conditions. The need for modeling incurs a substantial technical uncertainty because advances in the existing state-of-the-art predictive capabilities in materials sciences and related engineering disciplines are needed for both container and waste form materials. Because the risk of cost and schedule delays due to the 
inability to achieve the necessary understanding in long-term materials behavior are high, alternative waste package designs and materials selections are being evaluated to identify options that are potentially more stable in the postclosure environment.

Risk Level. Since the site characterization activities are largely within the range of existing technology, the overall technical risks to the success of the project are considered to be moderate to low level. Pending completion of the assessment of alternative waste package designs the potential need for advances in the state-of-the-art predictive capabilities for materials behavior cannot yet be determined.

\subsection{COST/SCHEDULE}

Considerations of ease and cost of repository siting, construction, operation, and closure, as defined in 10 CFR Part 960, require that reasonable schedule goals be achievable. Meeting the present schedule for LA submittal will depend on gaining early access to the site and on adequate funding to carry out the planned site characterization. The DOE is seeking ways to shorten the schedule while satisfying all technical and regulatory requirements.

However, there is a risk that some of the schedule dates for receiving waste will not be met. If a schedule delay materializes, costs will likely increase beyond current projections in an effort to recoup some lost time.

There are several factors that could contribute to a schedule delay, including lack of access for site characterization, lack of adequate funding, development of new materials technology, and difficulty in demonstration of regulatory compliance.

Risk Level. This is considered a high risk item requiring continuing Program and YMP management attention.

\subsection{OFFICE OF CIVILIAN RADIOACTIVE WASTE MANAGEMENT OUTREACH EFFORTS}

The OCRWM Program in general, and the YMP specifically, have suffered through a period of strained public interactions, at least a portion of which was associated with the public's pre-existing negative perception of nuclear technology. Since State and local governments, affected Indian tribes (none currently identified), and the public are all active participants in the program, there are risks that failure to maintain reasonable public interactions will.result in actions, such as litigation, which will cause significant delays and increased costs.

The OCRWM is committed to establishing public confidence in the program and is taking steps to address a number of items in an effort to improve public interactions. The YMP funds socioeconomic monitoring, environmental monitoring, and institutional and outreach programs and has held State and local government information exchanges to mitigate this risk and increase public confidence. 
Risk Level. Negative perceptions of State and local governments, interested citizens, and public interest groups present cost and schedule risks through various possible legal, regulatory, political, and civil actions. The risks associated with unsatisfactory public interactions can be high, as has been demonstrated. The program will continue to work to improve the relations and reduce the risk of additional confrontations. Presently, the risks of significant delay due to this factor are considered to be high.

\subsection{ENVIRONMENT}

The NWPA stipulates in Section 113 that site characterization activities must, to the maximum extent practicable, be conducted in a manner that minimizes any significant adverse impacts. However, no difficulties are anticipated in complying with substantive requirements of environmental regulations that apply to site characterization activities.

In 1986, DOE issued a site EA under the NWPA (DOE/RW-0073) which included an analysis of the environmental impacts of site characterization activities at the Yucca Mountain site. This analysis, which identified no potential adverse impacts that might be regarded as significant, is still considered valid. Subsequently an Environmental Monitoring and Mitigation Plan (EMMP) (DOE/RW-0208) was prepared to formulate how DOE would monitor potential environmental impacts and mitigate potential adverse impacts projected in the EA or identified through monitoring.

Risk level. Based on the EA analysis and the EMMP monitoring and mitigation activities that are being conducted, the risk of delaying the YMP due to significant environmental impacts is low.

\subsection{WORKER SAFETY AND HEALTH}

The types of activities that involve potential health and safety risks to the worker include motor vehicle transportation, office work, construction of aboveground and underground facilities (normally considered high hazard), operations in such facilities, laboratory testing, and other industrial tasks. A health and safety program (YMPO Safety and Health Plan, YMP/9037 ) is in place on the YMP to ensure that activities are carried out in accordance with applicable federal, state, and local laws, regulations, agreements, executive directives, consent decrees, and DOE Orders. Prior to beginning new surface-disturbing activities in the field, a comprehensive safety and health self-assessment of operations, facilities, equipment, and personnel was performed.

The Nevada Test Site (NTS) is supported by contractors that have a long history of operations on the site. It is anticipated that the YMP will continue to use these same contractors for work in the field, thereby taking advantage of their knowledge of health and safety requirements of the DOE on the NTS.

The DOE has maintained records of the safety performance of its operations and contractors that support the weapons test program. These records show that accident rates of 
these organizations in construction and motor vehicle operations are well below national industry averages.

Risk Level. The risk to personnel during site characterization, exclusive of construction, is considered to be moderate. Nevertheless, because the consequences of an injury or fatality on the YMP could be severe, safety and health require significant and continuing attention by management. 


\subsection{MANAGEMENT APPROACH}

Program management responsibilities are outlined in both the PMS Manual and the OCRWM QAPD. YMP management functions are outlined in this document and described in the PMP, which implements the basic segments of the YMP Management System for a Major Systems Acquisition (MSA) as provided for in DOE Order 4700.1. Responsibilities within the OCRWM for preparation, concurrences, and approval of management documents are established in Appendix F of the PMS Manual.

DOE policy is to use systems engineering in the technical management of all MSAs. Accordingly, the OCRWM Director has directed that systems engineering be used by all organizations participating in MGDS development. This requirement includes all divisions of the OCRWM, the DOE Project Offices, Federal organizations, national laboratories, and private contractors that support the Project Offices. In conformance with this policy, the YMP will use systems engineering to manage, integrate, interface, and document all technical activities on the YMP.

\subsection{PROGRAM MANAGEMENT}

Within the OCRWM, there are two distinct responsibilities assigned to different levels of program management. The OCRWM Program Office is responsible for external relations with other government agencies, providing guidance on regulatory policy interpretation, and tracking progress on programmatic milestones. The OCRWM is also responsible for preparation of the repository LA and major milestone documents such as the EIS. The YMP is responsible for conducting the management activities and technical investigations supporting the characterization of the Yucca Mountain site and for external interactions with State agencies (State of Nevada) and local governments. The YMP is responsible for implementing OCRWM directions, as well as supporting OCRWM efforts to prepare major programmatic documents, such as the EIS and the LA.

The management structure of the current OCRWM organization is presented in Figure 5-1a. The QA reporting structure is shown in Figure 5-1b. The balance of the OCRWM organization is presented in the PMS Manual (DOE/RW-0043) and details of the Office of Geologic Disposal (OGD) organization are presented in Figure 5.1c. Within the OCRWM, the responsibilities of the Associate Directors are defined in the approved mission and function statements in Appendix C of the PMS Manual.

\subsection{YUCCA MOUNTAIN SITE CHARACTERIZATION PROJECT MANAGEMENT}

As shown in Figure 5.1a, the Associate Director, OGD, reports directly to the Director, OCRWM. The Project Manager, YMPO, reports to the Associate Director, OGD. Appendix A to this plan contains the Project Charter, which delineates YMPO responsibilities, authority, and accountability. 


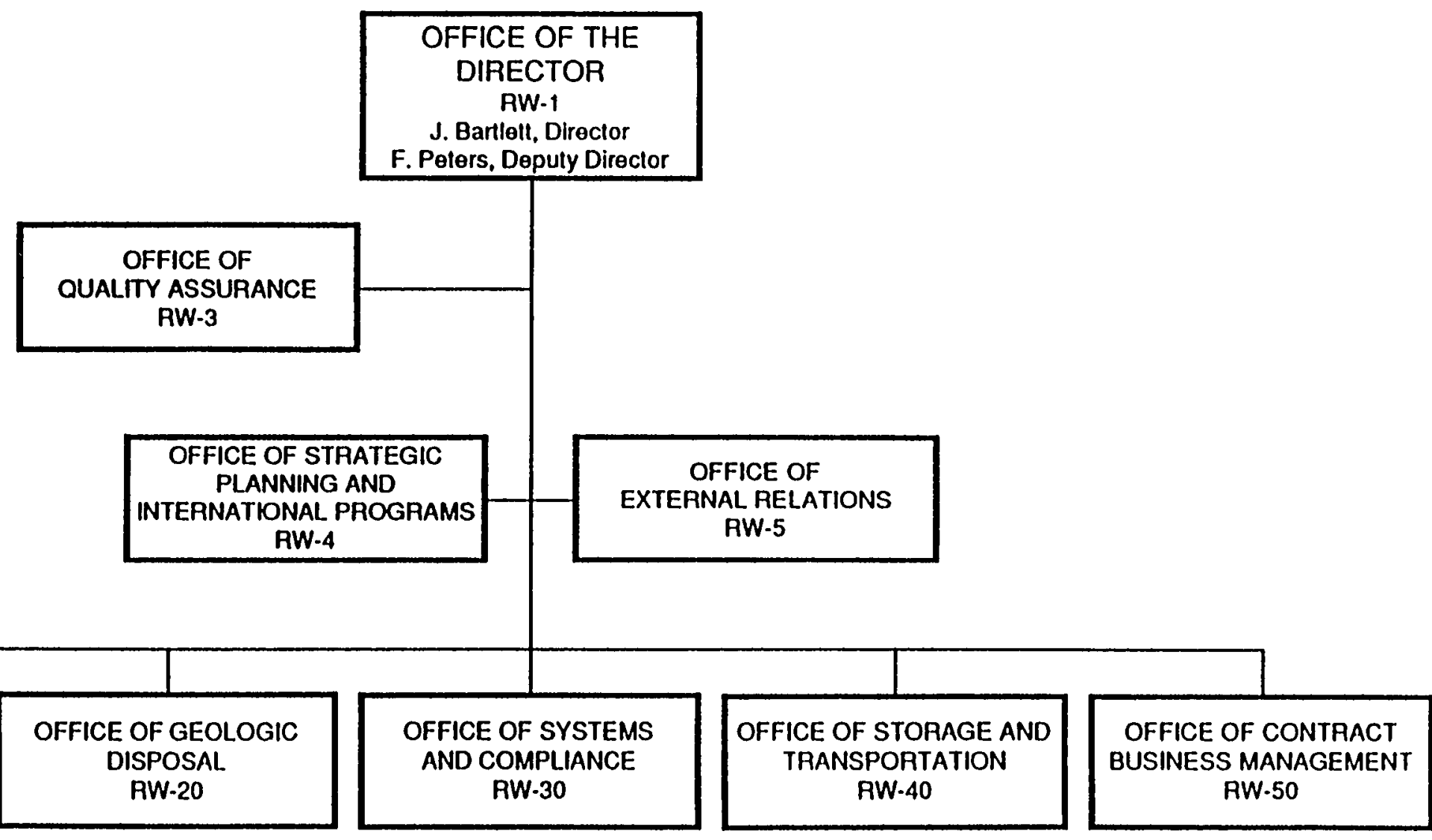

C. Gertz, Associate Director

Figure 5-1a. Office of Civilian Radioactive Waste Management Organization. 


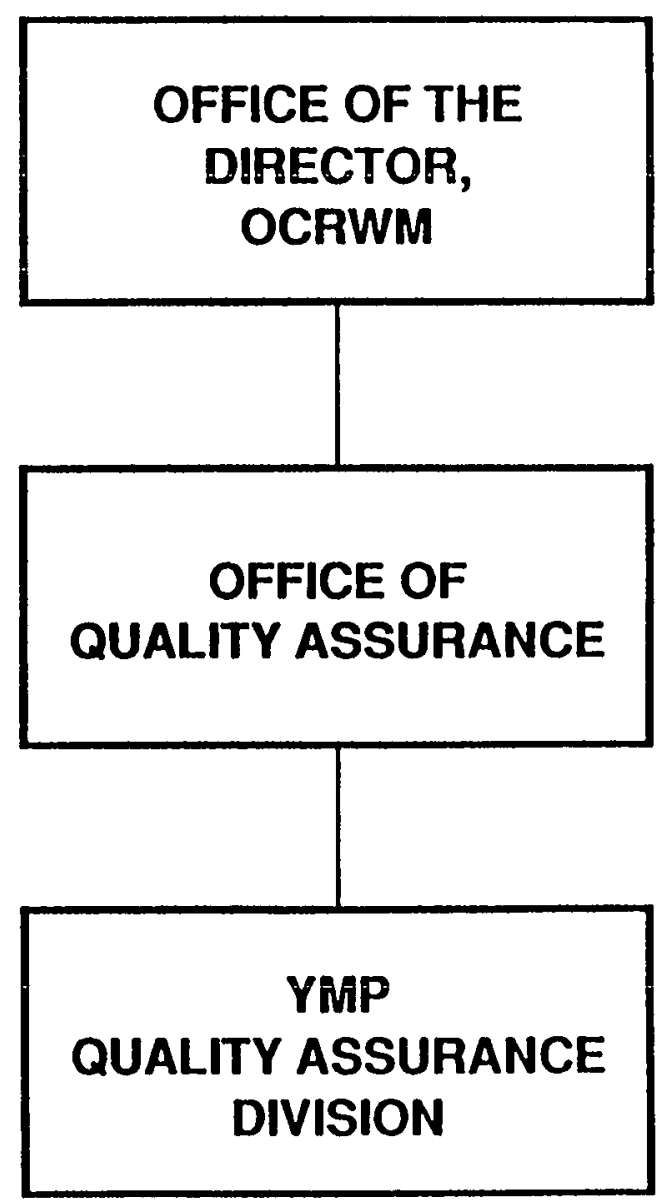




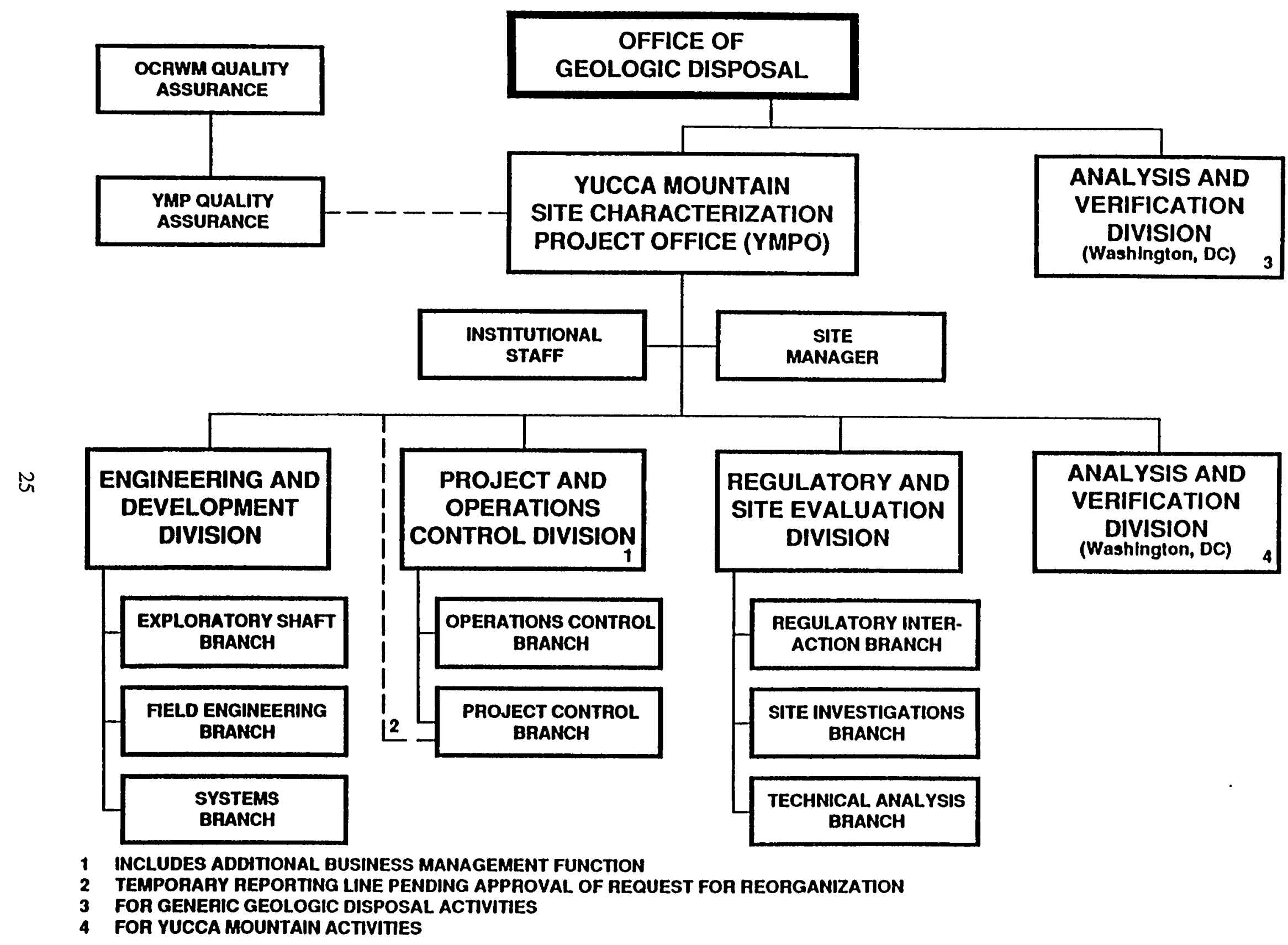

Figure 5-1c. Organization of the Olfice of Geologic Disposal. 


\subsection{ORGANIZATIONS AND RESPONSIBILITIES}

\subsubsection{PROGRAM RESPONSIBILITIES}

In managing the Civilian Radioactive Waste Program, the OCRWM is supported by DOE operation offices across the country, as shown in Figure 5-2. In the management of the MGDS development, the OCRWM maintains a number of contractors at several levels, listed in Appendix B. In addition to direct contractors, the OCRWM maintains a number of cooperative international agreements to exchange information with other countries and support activities that will prove mutually beneficial in waste isolation. The bilateral agreements and international projects in which the OCRWM participates are also listed in Appendix B.

\subsubsection{YUCCA MOUNTAIN SITE CHARACTERIZATION PROJECT RESPONSIBILITIES}

The organizations supporting the OCRWM Program and their-responsibilities are presented in the PMS Manual (DOE/RW-0043). The organizations supporting the program at the YMP level and their associated responsibilities are presented in Figure 5-3.

The responsibilities and authorities of major YMP Participants, including the national laboratories and other governmental agencies as well as private contractors, are described in Memoranda of Understanding (MOU), Memoranda of Agreement (MOA), Interagency Agreements, contracts, or management agreements of a similar nature. The functional relationships resulting from management agreements are included in YMP organization documents, such as the PMP, either directly or by reference. The approval date for the most recent version of the PMP is August, 1990.

Because the Yucca Mountain site is located on the western margin of the NTS, important interface relations must be maintained with the DOE Nevada Operations Office (NVO). Also, due to location and NTS operations, the YMP will continue to use DOE NVO contractors to perform work for the YMP. An MOA between the OCRWM, YMPO, and NVO provides guidelines for the continuing interface of activities.

\subsection{RELATIONSHIP WITH UTILITY INDUSTRY}

Section 302(a) of the NWPA authorizes the DOE (OCRWM) to enter into contracts with the owners and generators of commercial spent nuclear fuel (SNF) and HLW. The Standard Contract for Disposal of SNF and/or HLW (10 CFR Part 961) was established through the federal rulemaking process and finalized on April 18, 1983. The Disposal Contract establishes the requirements and operational responsibilities of both the DOE and the signatories on administrative matters, fees, terms of payment for disposal services, waste acceptance criteria, and waste acceptance procedures. 


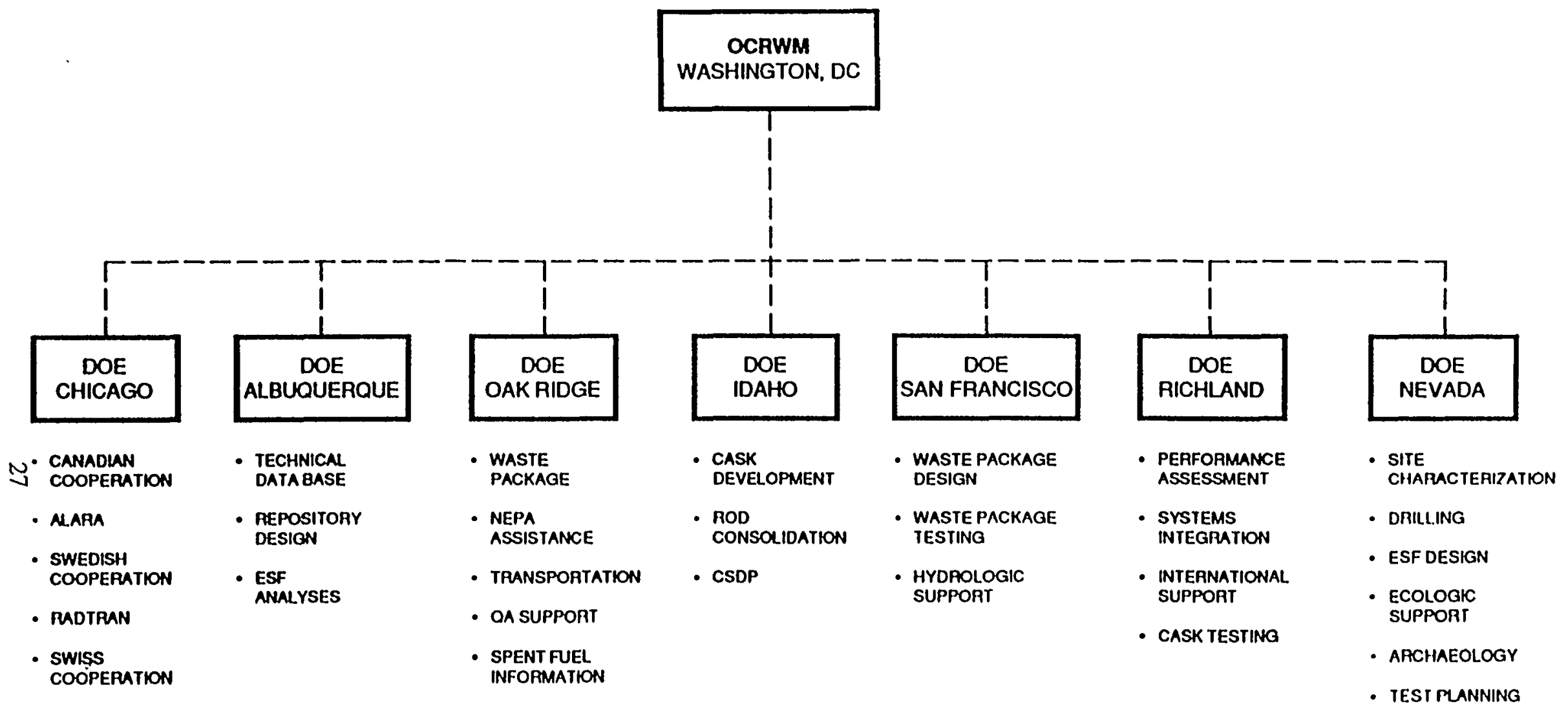

Figure 5-2. OCRWM Cooperating Oflices. 


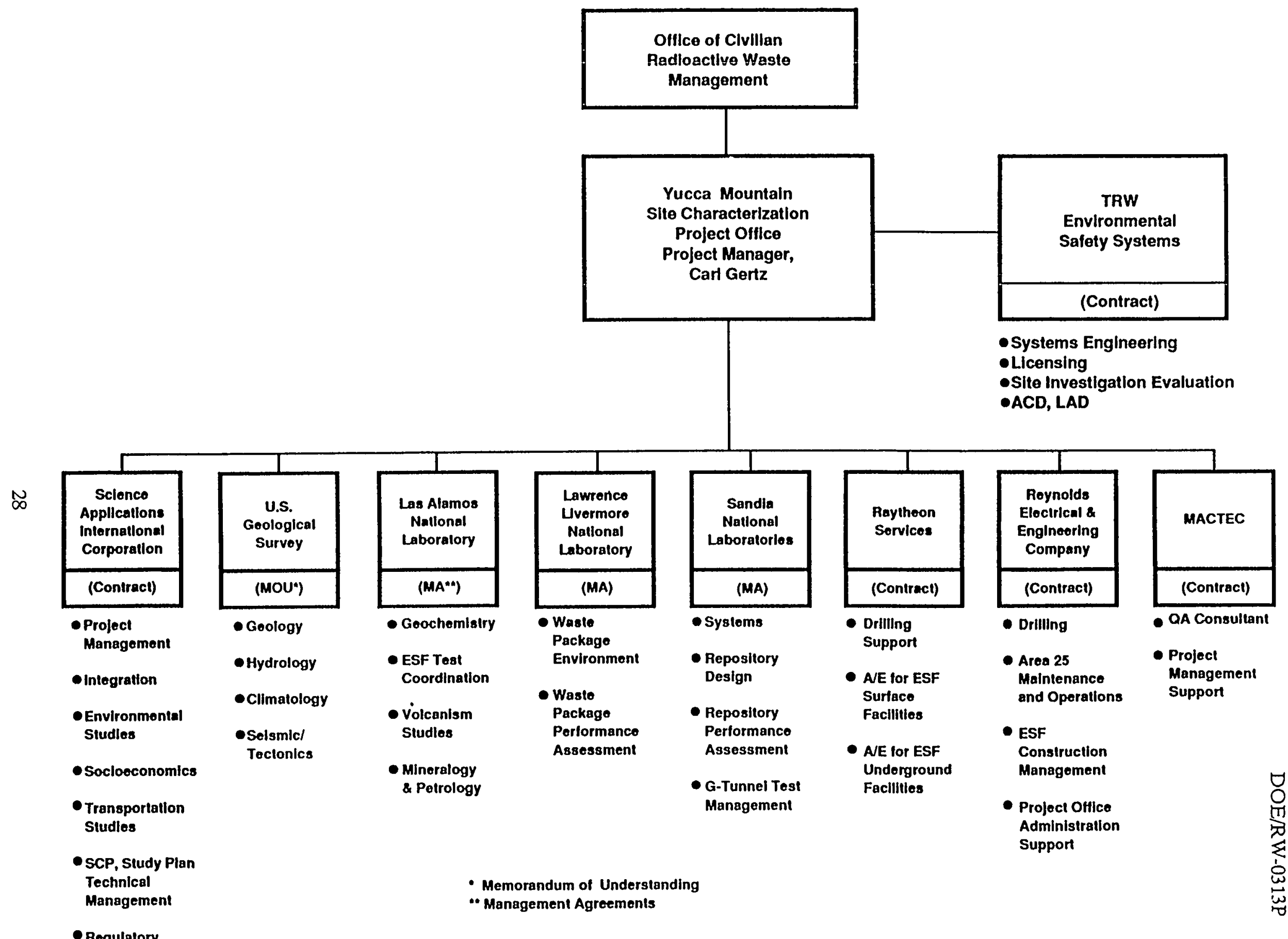

Figure 5-3 Roles of Project Participants 
To date, the DOE has entered into 80 such contracts with 66 owners, most of which are nuclear electric utility companies. The DOE interacts with the utilities, primarily through the Utility Nuclear Waste and Transportation Group, which represents the majority of contract signatories. This interaction consists of frequent information exchanges including periodic program reviews. The YMP will not deal directly with the electric utility industry except as requested by the OCRWM. However, the YMP shall.provide support to the OCRWM in the development of waste acceptance criteria and procedures.

The DOE cooperates with the Edison Electric Institute and Electric Power Research Institute in the independent evaluation of its programmatic efforts.

\subsection{YUCCA MOUNTAIN SITE CHARACTERIZATION PROJECT MANAGEMENT CONTROL SYSTEMS}

The OCRWM has implemented the DOE project management system policies contained in DOE Order 4700.1 through the program-specific requirements described in the PMS Manual (DOE/RW-0043). The OCRWM is in the process of revising its program-specific requirements and related YMP control documentation to incorporate the revised DOE project management system requirements described in SEN-27-90 and DOE Notice 4700.4. The OCRWM's PMS has the following key features:

- A hierarchy of technical, cost, and schedule baselines at the Program, Project, and contractor (where appropriate) levels.

- A hierarchy of change control boards at the Program, Project, and contractor (where appropriate) levels that control changes to these technical, cost, and schedule baselines that exceed predetermined thresholds.

- Integrated Project planning and control system compliance with the DOE cost and schedule control systems criteria for contractor performance measurement described in DOE Order 2250.1C

In addition, the OCRWM is subject to the following controls by the Department's Acquisition Executive:

- Approval of Level 0 technical (scope), cost, and schedule baseline changes that exceed predetermined thresholds

- ESAAB reviews at key decision points prior to the release of funds

- Annual Energy System Acquisition Reviews (ESARs)

The YMP has been designated by DOE Order $4240.1 \mathrm{~J}$ as an MSA. The YMP has developed a Planning and Control System to integrate YMP technical scope, cost, and schedule. Work performance is measured monthly and variances from planned work are reported. Contractors and other Participants responsible for a cost and/or schedule variance that exceeds predetermined thresholds must submit a variance analysis. This analysis includes the cause and 
impact of the variance plus proposed corrective action to minimize the cost overrun or schedule slip.

The Project Manager submits a quarterly Project Manager's Progress Report to the Director, OCRWM, which provides copies to the Office of Program/Project Management. This report is consistent with the requirements and guidelines for MSA reporting stated in DOE Order 4700.1.

\subsubsection{MANAGEMENT INFORMATION}

YMP information and documentation is to be managed through an automated system that captures and controls appropriate data. The system is to ensure that information is controlled, and made available as needed by Participants. The information system shall consist of various components to manage administrative, tracking, and contractual information necessary to ensure timely and controlled bases for analyses, documentation, and decision making. The system will be used to track technical milestones and document development, and will be described in the PMP. In addition, the system will serve as a capture station for YMP records that are to be submitted to the Licensing Support System. 


\subsection{ACQUISITION STRATEGY}

The Associate Director, OGD, shall prepare an annual procurement plan to provide input to the OCRWM annual procurement plan prepared by the Director of the Contract Management Division. Most procurements shall be subcontracted through prime contractors who shall conduct work under the direction of the YMPO Project Manager. Subcontract management is carried out in accordance with procurement regulation and is described in the PMP. Field procurements shall be conducted under the joint cognizance of the Project Manager and the contracting officer. Plans for YMP-initiated procurements with full and open competition whose total estimated value exceeds $\$ 1$ million shall be concurred in by the cognizant OCRWM Associate Director and, in all cases, the Associate Director for Contract Business Management.

The Advance Acquisition or Assistance Plan prepared by the YMPO Project Manager as an annex to the PMP shall describe the contractual means by which the YMP's acquisition strategy shall be carried out. The acquisition strategy shall provide a brief description of the contractual basis of the YMP and reflect the management concepts that shall be used in directing and controlling the YMP. Advance acquisition plans for the MGDS shall be concurred in by the Associate Director, Contract Business Management; Associate Director, Storage and Transportation; Associate Director, Geologic Disposal; Associate Director, Program and Resource Management; and the cognizant contracting officer. The plans shall be approved by the Director, OCRWM. Individual acquisition strategies or business plans shall be prepared in accordance with established policies and procedures, including DOE Acquisition Regulations and DOE Order $4200.1 \mathrm{C}$, and shall be required in advance of requests for significant funding. Reviews of advance plans and strategies shall be coordinated among the Associate Directors and the YMPO Project Manager. Acquisition planning for phases beyond submittal of the LA is not yet underway. This section of the Project Plan will be expanded to add those plans as the YMP progresses.

Acquisition planning is complete for the characterization and ESF design portions of the site characterization phase as described in Section 3 of this Project Plan. The strategy for site characterization activities involves (1) continued reliance on existing contracts and agreements with national laboratories and other organizations shown in Figure 5.3 for the conduct of scientific investigations, and (2) procurement of additional contractors for MGDS development as noted below. The OCRWM has employed a Management and Operating contractor to ensure that the first repository candidate site is characterized consistent with the NWPA and to serve as the architect/engineer for design of the MGDS. That contractor will also provide the strategy options, leadership, and resources to assist the DOE in obtaining a license and, in later phases of the Program, a construction authorization from the NRC. The Project Manager shall provide additional information on acquisition plans in the PMP as required by the PMS Manual. The larger OCRWM and YMPO contracts and agreements are listed in Appendix B. 


\subsection{YUCCA MOUNTAIN SITE CHARACTERIZATION PROJECT SCHEDULE}

The Project schedule baseline is included in the YMP Cost and Schedule Baseline, YMP/CM-0015, referenced in Appendix D. The summary of Baseline Information Table in Appendix D identifies the schedule baseline hierarchy, which includes Acquisition Executive (Level 0), program (Level 1), and Project (Level 2) milestones as well as key decision points requiring $\mathrm{ESAAB}$ approval. 


\subsection{RESOURCES PLAN}

The resources plan for the total YMP through FY 1992 is shown in Appendix E. The FY 1983 through 1990 data reflect actual costs from Project inception on January 7, 1983. The FY 1991 data reflect the Congressional appropriation. The FY 1992 data reflect the FY 1992 Congressional Conference Recommendation. Operating expenses and capital equipment are integrated into the WBS element breakout as well as shown separately along with manpower. Future year funding is omitted because the FY 1993 budget process addresses an ESF configuration different from the two-shaft configuration addressed in this Project Plan.

The Total Project Cost (TPC) for the YMP and the Total Estimated Cost (TEC) for the ESF are shown in the Summary of Baseline Information table in Appendix D. 


\subsection{CONTROLLED ITEMS}

The controlled items are the hierarchy of technical, cost and schedule baselines summarized in the Summary of Baseline Information table in Appendix D. The baseline change control thresholds related to this hierarchy of baselines are included in the Summary of Change Control Thresholds table in Appendix D. These baselines are controlled by the Project, Program, and ESAAB Change Control Boards. 


\subsection{SCHEDULED DECISION POINTS}

ESAAB approval is required for the YMP key decisions (KDs) shown in the Summary of Cost and Schedule Baseline Information table in Appendix D. The first two KDs, KD-X, Start New Surface-Based Testing, and KD-2, Start Final ESF Title II Design, will be combined into one ESAAB review scheduled to precede $\mathrm{KD}-2$. In a memorandum of agreement between OCRWM and the Office of Program/Project Management, dated October, 18,1990 , approval was granted to begin limited new surface-based testing activities pertaining to Midway Valley trenching and calcite-silica testing prior to ESAAB approval of $\mathrm{KD}-\mathrm{X}$. 


\section{REFERENCES}

DOE (U.S. Department of Energy), 1990. Baseline Change Control Process at the Executive Level, DOE Notice 4700.4, Washington, D.C.

DOE (U.S. Department of Energy), 1987. Competition in Contracting, DOE Order 4200.1C, Washington, D.C.

DOE (U.S. Department of Energy), 1991. Designation of Major System Acquisitions \& Major Projects, DOE Order 4240.1J, Washington, D.C.

DOE (Office of Civilian Radioactive Waste Management), 1989. Program Management System Manual, DOE/RW-0043, Washington, D.C.

DOE (U.S. Department of Energy), 1987. Project Management System, DOE Order 4700.1, Washington, D.C.

DOE (U.S. Department of Energy), 1988. Site Characterization Plan, Yucca Mountain Site, Nevada Research and Development Area, Nevada, DOE/RW-0198, Washington, D.C.

DOE (U.S. Department of Energy), 1990. Strengthening the DOE Project Management System, SEN 27-90, Washington, D.C.

DOE/RW (U.S. Department of Energy/Office of Civilian Radioactive Waste Management), 1986. Environmental Assessment, DOE/RW-0073, Washington, D.C.

DOE/RW (U.S. Department of Energy/Office of Civilian Radioactive Waste Management), 1988. Environmental Monitoring and Mitigation Plan, DOE/RW-0208, Washington, D.C.

DOE/RW (U.S. Department of Energy), 1987. Issues Hierarchy for a Mined Geologic Disposal System (OGR/B-10), DOE/RW-0101, Washington, D.C.

DOE/RW (U.S. Department of Energy/Office of Civilian Radioactive Waste Management), 1990. OCRWM Program Cost and Schedule Baseline, DOE/RW-0253, Washington, D.C.

DOE/RW (U.S. Department of Energy/Office of Civilian Radioactive Waste Management), 1990. Program Change Control Procedure, DOE/RW-0223, Washington, D.C.

DOE/RW (U.S. Department of Energy/Office of Civilian Radioactive Waste Management), 1990. Quality Assurance Program Description, DOE/RW-0215, Washington, D.C. 
DOE/RW (U.S. Department of Energy/Office of Civilian Radioactive Waste Management), 1990. Quality Assurance Requirements Document, DOE/RW-0214, Washington, D.C.

DOE/RW (U.S. Department of Energy/Office of Civilian Radioactive Waste Management), 1989. Secretary's Report to Congress on Reassessment of the Civilian Radioactive Waste Management Program, DOE/RW-0247, Washington, D.C.

DOE/RW (U.S. Department of Energy/Office of Civilian Radioactive Waste Management), 1990. Waste Management System Description, DOE/RW-0270P, Washington, D.C.

DOE/RW (U.S. Department of Energy/Office of Civilian Radioactive Waste Management), 1990. Waste Management System Requirements, Vol. I, DOE/RW-0264, Washington, D.C.

DOE/RW (U.S. Department of Energy/Office of Civilian Radioactive Waste Management), 1990. Waste Management System Requirements, Vol. IV, DOE/RW-0268P, Washington, D.C.

NWPA (Nuclear Waste Policy Act), 1983. Nuclear Waste Policy Act of 1982, Public Law 97-425,42 USC 10101-10226, Washington, D.C.

NWPAA (Nuclear Waste Policy Act Amendment), 1987. Nuclear Waste Policy Amendments Act of 1987, Public Law 100-203, 100th Congress, Washington, D.C.

YMP (Yucca Mountain Site Characterization Project), 1990. Yucca Mountain Project Project Management Plan, YMP/88-2, Las Vegas, Nevada.

YMP (Yucca Mountain Site Characterization Project), 1990. YMPO Safety and Health Plan. YMP/90-37. Las Vegas, NV.

10 CFR Part 60 (Code of Federal Regulations), 1986. Title 10, "Energy," Part 60, "Disposal of High-Level Radioactive Wastes in Geologic Repositories," U.S. Government Printing Office, Washington, D.C.

10 CFR Part 960 (Code of Federal Regulations), 1984. Title 10, "Energy," Part 960, "General Guidelines for the Recommendation of Sites for Nuclear Waste Repositories," U.S. Government Printing Office, Washington, D.C.

40 CFR Part 191 (Code of Federal Regulations), 1985. Title 40, "Protection of Environment," Part 191, "Environmental Standards for the Management and Disposal of Spent Nuclear Fuel, High-Level and Transuranic Radioactive Wastes," U.S. Government Printing Office, Washington, D.C. 


\section{APPENDIX A}

\section{PROJECT CHARTER}

FOR THE YUCCA MOUNTAIN SITE CHARACTERIZATION PROJECT 
DOE/RW-0313P

PROJECT CHARTER FOR THE YUCCA MOUNTAIN SITE CHARACTERIZATION PROJECT

\section{INTRODUCTION}

The purpose of the Project Charter is to clearly delineate management responsibility, authority, and accountability for the YMP. It establishes the operational management relationships between the OCRWM and YMPO. The Project Charter is based upon the requirements and guidance provided by DOE Order 4700.1.

\section{MANAGING ORGANIZATION}

The managing organization for the YMPO is the OCRWM. The OCRWM consists of the following eight Offices: QA, Strategic Planning and International Programs, External Reiations, Systems and Compliance, Contract Business Management, Storage and Transportation, Geologic Disposal, and Program and Resources Management. Activities performed by the YMPO are managed by the OGD.

The OCRWM reviews, monitors, and evaluates the YMP management and technical documents. The OCRWM will approve the License Application and will approve and/or concur on licensing documents, technical documents, and management plans for major programmatic activities. Documents subject to OCRWM review are listed in Appendix F of the PMS Manual. Documents will also be nominated for review from the YMPO status reports on documents scheduled for completion within the upcoming six-month interval.

\section{YUCCA MOUNTAIN SITE CHARACTERIZATION PROJECT MANAGER}

The Project Manager of the YMP is Carl P. Gertz. Mr. Gertz was appointed to the position of Project Manager for the YMP (then the Nevada Nuclear Waste Storage Investigations Project) in August 1987. On February 24, 1991, Mr. Gertz was also designated Associate Director for Geologic Disposal, OCRWM.

LOCATION OF THE YUCCA MOUNTAIN SITE CHARACTERIZATION PROJECT OFFICE

The YMPO, and the Project Manager's office, are located at the following address:

Yucca Mountain Site Characterization Project Office

Carl P. Gertz, YMP Project Manager

101 Convention Center Drive

Las Vegas, Nevada 89109 


\section{YUCCA MOUNTAIN SITE CHARACTERIZATION PROJECT ORGANIZATION/MISSION ASSIGNMENTS}

Organizations that participate in YMP activities consist of

- The OCRWM, which provides program planning, direction, and control, as well as interface with other agencies and Congress

- Contractors under the direction and control of the OCRWM

- Other DOE offices supporting the OCRWM

- The YMPO, which provides YMP management and control

- Contractors under the direction and control of the YMPO

- Selected DOE operations offices

- DOE national laboratories

- Federal agencies external to the DOE

The OCRWM and YMP organizations are depicted in Figures 5-1 and 5-3, respectively, of the Project Plan. The responsibilities of the various OCRWM offices and the assignment of responsibility to field offices in support of the OCRWM are stated in the PMS Manual (DOE/RW-0043).

Major YMP Participants consist of scientific and technical organizations (e.g., the national laboratories; cooperating government agencies; and engineering, design, and construction contractors). The organizations, roles, and responsibilities of the YMPO and Participants shall be described in the PMP.

The YMPO has defined interface responsibilities with other departmental elements and interacts with several external organizations. Departmental interfaces exist with the Offices of the Inspector General, General Counsel, Environmental Restoration and Waste Management, and Environment, Safety and Health concerning matters related respectively to accountability, legal positions, defense waste, and environmental concerns. In addition, the YMP utilizes facilities and the infrastructure of the NTS, including design and construction support, as well as support and interaction in legal security and classification, personnel and environmental matters. The appropriate MOU's, management agreements, procedures, protocols, and contracts with NVO are in place.

The primary external organizations with which the YMP interacts are the NRC and the NWTRB. NRC interactions deal with issues relevant to repository licensing and are 
governed by an Interagency Agreement. Procedural and policy statements are reviewed and approved by the cognizant Associate Director with respect to these organizations. The Department of Labor and OCRWM have agreed on interactions through an MOU; therefore, all interactions with the MSHA and OSHA will be reviewed and approved by the Associate Director of OGD in accordance with the MOU. Interactions with external organizations such as the National Academy of Sciences, EPA, General Accounting Office, Edison Electric Institute, Electric Power Research Institute, Department of the Interior, Fish and Wildlife Service, National Park Service, Bureau of Land Management, State of Nevada and its Offices, and the affected counties generally involve furnishing requested information and typically are less formal and not directly governed by agreements or procedures. YMP interactions with these organizations are informal and will not establish policy or make program commitments without direct coordination and approval of the cognizant Associate Director. All interaction will be documented as appropriate through meeting minutes or memos and notification provided to the affected cognizant Associate Director. The OCRWM Director is the point of contact for any organization not identified herein.

\section{AUTHORITY AND RESPONSIBILITIES OF THE PROJECT MANAGER}

The responsibility for managing the disposal of spent nuclear fuel and HLW is assigned to the OCRWM by the NWPA. The Project Manager for the YMP has the authority to carry out the responsibilities contained in this Project Charter and the associated Project Plan.

The Project Manager is authorized and directed to conduct the day-to-day management of the YMP in accordance with the direction and guidance provided by the Director, OCRWM (or designated representative). This direction and guidance is provided by the PMS Manual; subtier documents; DOE Orders, regulations, codes, and other requirements referenced in the PMS Manual; and program direction issued or authorized by the Director, OCRWM (or designee).

The Project Manager is authorized to direct YMP Participants to perform work in accordance with the approved YMP budget; program milestones; program technical and quality objectives; program requirements; and program-level contractual documents, e.g., MOU and letters of agreement. The Project Manager is authorized to manage the work of the YMP in accordance with those plans, requirements, specifications, and baselines that are prepared by the YMP.

In carrying out these general responsibilities and in accordance with his designated authority, the Project Manager shall manage and direct activities in accordance with DOE Order 4700.1 and OCRWM programmatic guidance and policies to: 
- Prepare and approve key YMP documents, including the PMP; MGDS Systems Engineering Management Plan; documents listed in the PMP document hierarchy; and other management documents as specified in the PMS Manual.

- Establish QA, environmental, socioeconomic, and safety programs in accordance with requirements and guidelines provided by the OCRWM and in compliance with applicable Federal, State, and local laws; Federal regulations; and DOE orders. (In preparing NEPA documentation, the Project Manager shall obtain guidance from the appropriate field organization unit responsible for environment, safety and health and from the Assistant Secretary for Environment, Safety and Health.)

- Prepare Work Authorization System YMP budgets and issue allocation of budgets to YMP Participants based upon the approved budget.

- Institute YMP controls for quality, cost, schedule, and technical activities that comply with program requirements.

- Develop YMP procedures for the conduct of YMP activities and ensure that YMP Participants have satisfactory documents to control YMP- related work.

- Structure the YMP organization consistent with the OCRWM program, develop resources, and provide training to ensure that a satisfactory number of qualified personnel are available as required by the YMP.

- Manage work being performed by the Management and Operating Contractor within the Project Manager's functional area of responsibility.

- Direct, manage, and measure the performance of YMP' and Participant organizations in the creation of designs and implementation of YMP plans. Provide for corrective actions to correct deficiencies and improve performance when required.

- Provide for YMP technical and management reviews and furnish progress reports and other required reports to the OCRWM in support of document preparation and interagency requests. Communicate with the OCRWM on all changes to schedule, budget, and planning scope.

- Represent the OCRWM and YMP in communications at the state and local levels with governmental representatives, the public, and representatives of affected Indian Tribes. 
- Initiate actions to award grants to eligible state and local jurisdictions, as prescribed by the NWPA, in accordance with DOE regulations and program office guidance.

- Initiate procurement actions, in accordance with federal and DOE procurement regulations, for contracts and subcontracts required to support YMP activities. These include contracts for consulting services, as well as for materials, equipment, and engineering/construction work.

- Participate within the OCRWM, as requested, in the establishment of policy and guidelines for the management of the YMP. Interact with the NRC, EPA, and other government agencies under direction of the OCRWM.

- Provide for the acquisition of land and the required permits and licenses to perform the site investigations, including ESF development, and for characterizing the site.

- Support preparation of the LA and EIS.

- Develop, issue, and implement institutional and outreach plans as directed and approved by the Program Office.

- Provide configuration management system to establish, document, and control the YMP's baseline consistent with the OCRWM program. Institute a configuration control system and a program of configuration audits to ensure compliance with the system.

- Manage design review, construction review, and construction management activities for the ESF.

- Prepare and execute a complete test plan to ensure full technical performance capabilities of the YMP's baseline.

\section{PROJECT MANAGER REPORTING}

The Project Manager reports to the Associate Director for Geologic Disposal, who in turn reports directly to the Director, OCRWM. The direct-line reporting of the Project Manager to the OCRWM has been established to fix authority and responsibility and facilitate coordination and communication. The reporting of periodic progress shall be conducted as specified in Section 5.5 of the Project Plan. 


\section{SPECIAL INSTRUCTIONS, DELEGATION OF AUTHORITY}

The Project Manager is instructed to manage the activities of the YMP, including those performed by federal personnel assigned to the YMPO and those performed by contractors, national laboratories, and cooperating government agencies, pursuant to policies and procedures established in appropriate contracts, MOAs, and similar documents that have been approved by the responsible OCRWM office and the field office responsible for the contractor involved. These documents shall be maintained by the YMPO as the basis for the working arrangements among the affected parties.

An MOA describes the continuing working relationship between the YMP and the NVO and notes that the Project Manager has a specific responsibility for concurrence and coordination of activities with the Manager, NVO, to ensure direct input to any decision that could adversely affect the weapons program.

Authority for the direction and approval of YMP activities is granted to the Project Manager within the limits and guidelines provided in the PMS Manual and in accordance with the approved YMP budget.

\section{YUCCA MOUNTAIN SITE CHARACTERIZATION PROJECT REQUIREMENTS FOR TRANSITION/TERMINATION PLAN}

The NWPA mandates the selection, characterization, licensing, development, operation, and, ultimately, the closure and decommissioning of an MGDS for the disposal of HLW and spent nuclear fuel. The OCRWM was established by the NWPA to carry out the overall civilian radioactive waste management program. The Director, OCRWM, has assigned to the Project Manager, YMPO, the responsibility for the characterization of the Yucca Mountain site.

In the event that the site is successfully characterized and selected for development as a repository, it is currently planned that the YMP will continue to manage field activities through the final closure and decommissioning of the repository. However, the name may be changed to reflect the continuing activities of the YMP. A Transition Plan detailing the YMP's transition to an operating organization will be developed if the site is selected and upon submittal to the NRC of the repository LA. In addition, because development of the repository will continue long after operations have started, there will be the need for a plan for coordinating the development and operation of the repository.

If, at any time, it is determined that the YMP should be terminated, a termination and/or transition plan will be required. The plans for final closure, decommissioning, and site reclamation, including permanent site markings and continuing post-closure monitoring, will be addressed in appropriate YMP regulatory and engineering documents, such as License Amendment Applications and the MGDS Reclamation Implementation Plan. 
DOE/RW-0313P

APPENDIX B

CONTRACTS AND AGREEMENTS 


\begin{tabular}{llll}
\hline & & BRANCH CHIEF/ & CONTRACT NUMBER/ \\
ORGANIZATION & FUNCTION (TYPE) & YMP OFFICER & DATE
\end{tabular}

Contracts and Agreements

1. National Academy of Sciences

2. U.S. Geological Survey

3. TRW

Environmental Safety Systems Inc.

4. Dept. of Interior; Bureau of Land Management (BLM)

5. Science Applications International Corp. (SAIC)
Publications on Rock

Mechanics/Tunneling

Technology (Financial

Assistance Award)

Geotechnical Support

(Interagency)

Technical Direction

Repository A/E

(M\&0)

Administer Right-of-Way

Reservation (Interagency)

Integrate YMPO activities.

Provide technical and

management support.

(Support Services)

\section{S. Brocoum/ \\ J. Stockey/ \\ B. Collins}

S. Brocoum/

J. Stockey/

G. Roseboom

V. Trebules/

TBD

NVO Contracting

Officer/TBD

C. Gertz/J. Nelson
Grant

DE-FG01-90RW00214/

Mar 90-Feb 93

MOU/

Sept 87-Sept 91

DE-AC01-91RW00134/

Feb 91-Feb 01

DE-AI08-88NV10738/

TBD

DE-AC08-87NV10576/

Mar 87-Mar 97 
CONTRACTS AND AGREEMENTS (continued)

\begin{tabular}{|c|c|c|c|}
\hline ORGANIZATION & FUNCTION (TYPE) & $\begin{array}{l}\text { BRANCH CHIEF/ } \\
\text { YMP OFFICER }\end{array}$ & $\begin{array}{l}\text { CONTRACT NUMBER/ } \\
\text { DATE }\end{array}$ \\
\hline $\begin{array}{l}\text { 6. Dept. of Interior; U.S. } \\
\text { Geological Survey } \\
\text { (USGS) }\end{array}$ & $\begin{array}{l}\text { Characterize geology, } \\
\text { hydrology, tectonism, and } \\
\text { seismicity (Interagency) }\end{array}$ & C. Gertz/L. Hayes & $\begin{array}{l}\text { DE-AI08-78ET } 44802 / \\
\text { May 78-Dec } 99\end{array}$ \\
\hline $\begin{array}{l}\text { 7. Reynolds Electrical and } \\
\text { Engineering Company, } \\
\text { Inc. (REECo) }\end{array}$ & $\begin{array}{l}\text { Site construction, drilling, and } \\
\text { mining }(\mathrm{M} \& \mathrm{O})\end{array}$ & $\begin{array}{l}\text { C. Gertz/ } \\
\text { R. Pritchett }\end{array}$ & $\begin{array}{l}\text { DE-AC08-89NV10630/ } \\
\text { Oct } 88-\operatorname{Sep} 93\end{array}$ \\
\hline $\begin{array}{l}\text { 8. Raytheon Services, } \\
\text { Nevada (RSN) }\end{array}$ & $\begin{array}{l}\text { Architect-engineer for the } \\
\text { surface and subsurface } \\
(\mathrm{M \& O})\end{array}$ & C. Gertz/TBD & $\begin{array}{l}\text { DE-AC08-91NV10833/ } \\
\text { Nov } 90-\text { Nov } 95\end{array}$ \\
\hline $\begin{array}{l}\text { 9. MAC Technical Services } \\
\text { Company, Inc., } \\
\text { (MACTEC) }\end{array}$ & $\begin{array}{l}\text { Management support, quality } \\
\text { verification } \\
\text { (Support Services) }\end{array}$ & C. Gertz/R. Lowder & $\begin{array}{l}\text { DE-AC08-87RL10840/ } \\
\text { Apr 87-Mar } 97\end{array}$ \\
\hline $\begin{array}{l}\text { 10. EG\&G Energy } \\
\text { Measurements, Inc. } \\
\text { (EG\&G) }\end{array}$ & $\begin{array}{l}\text { Instrumentation support, } \\
\text { environmental measurements, } \\
\text { and GIS support } \\
\text { (Support Services) }\end{array}$ & $\begin{array}{l}\text { NVO Contracting } \\
\text { Officer/P. Zavattaro }\end{array}$ & $\begin{array}{l}\text { DE-AC08-88NV10617/ } \\
\text { Jan 88-Dec } 92\end{array}$ \\
\hline
\end{tabular}


CONTRACTS AND AGREEMENTS (continued)

\begin{tabular}{|c|c|c|c|}
\hline ORGANIZATION & FUNCTION (TYPE) & $\begin{array}{l}\text { BRANCH CHIEF/ } \\
\text { YMP OFFICER }\end{array}$ & $\begin{array}{l}\text { CONTRACT NUMBER/ } \\
\text { DATE }\end{array}$ \\
\hline $\begin{array}{l}\text { 11. Defense Nuclear Agency } \\
\text { subcontract; Pan Am }\end{array}$ & $\begin{array}{l}\text { Photographic support } \\
\text { (Support Services) }\end{array}$ & C. Gertz/TBD & $\begin{array}{l}\text { DE-AI08-88NV10751/ } \\
\text { TBD }\end{array}$ \\
\hline $\begin{array}{l}\text { 12. Wackenhut Services, Inc. } \\
\text { (WSI) }\end{array}$ & $\begin{array}{l}\text { Security services. } \\
\text { (Support Services) }\end{array}$ & $\begin{array}{l}\text { NVO Contracting } \\
\text { Officer/TBD }\end{array}$ & $\begin{array}{l}\text { DE-AC08-87NV10559/ } \\
\text { TBD }\end{array}$ \\
\hline $\begin{array}{l}\text { 13. Desert Research } \\
\text { Institute (DRI) }\end{array}$ & $\begin{array}{l}\text { Archaeological investigations } \\
\text { for environmental program } \\
\text { (Support Services) }\end{array}$ & $\begin{array}{l}\text { NVO Contracting } \\
\text { Officer's Technical } \\
\text { Representative/TBD }\end{array}$ & $\begin{array}{l}\text { DE-AC08-90NV10845/ } \\
\text { TBD }\end{array}$ \\
\hline $\begin{array}{l}\text { 14. Computer Sciences } \\
\text { Corporation (CSC) }\end{array}$ & $\begin{array}{l}\text { Software and hardware } \\
\text { support (Support Services) }\end{array}$ & $\begin{array}{l}\text { NVO Contracting } \\
\text { Officer's Technical } \\
\text { Representative/TBD }\end{array}$ & $\begin{array}{l}\text { DE-AC08-90NV10811/ } \\
\text { TBD }\end{array}$ \\
\hline $\begin{array}{l}\text { 15. Dept. of Interior; } \\
\text { Bureau of Mines } \\
\text { (USBM) }\end{array}$ & $\begin{array}{l}\text { Review mining impacts of } \\
\text { ESF design plans } \\
\text { (Interagency) }\end{array}$ & $\begin{array}{l}\text { NVO Contracting } \\
\text { Officer/TBD }\end{array}$ & $\begin{array}{l}\text { DE-AI08-88NV10776/ } \\
\text { TBD }\end{array}$ \\
\hline $\begin{array}{l}\text { 16. U.S. Army Corps of } \\
\text { Engineers (CoE) }\end{array}$ & $\begin{array}{l}\text { Review civil and structural } \\
\text { plans for ESF surface } \\
\text { installation (Interagency) }\end{array}$ & $\begin{array}{l}\text { NVO Contracting } \\
\text { Officer/TBD }\end{array}$ & $\begin{array}{l}\text { DE-AI08-88NV10755/ } \\
\text { TBD }\end{array}$ \\
\hline
\end{tabular}




\begin{tabular}{|c|c|c|c|}
\hline ORGANIZATION & FUNCTION (TYPE) & $\begin{array}{l}\text { BRANCH CHIEF/ } \\
\text { YMP OFFICER }\end{array}$ & $\begin{array}{l}\text { CONTRACT NUMBER/ } \\
\text { DATE }\end{array}$ \\
\hline
\end{tabular}

17. U.S. Environmental Protection Agency (EPA)

18. Sandia National Laboratories (SNL)

19. Los Alamos National Laboratory (LANL)

20. Lawrence Livermore National Laboratory (LLNL)

\section{Lawrence Berkeley} Laboratory (LBL)
Radiological monitoring

(Interagency)

Systems development, performance assessment, data bases development, rock properties data, seal performance, and technical assistance $(\mathrm{M} \& \mathrm{O})$

Nuclide migration, geochemistry, mineralogy/petrology, subsurface test coordination, and performance assessment

Waste package development, material testing, and performance analysis ( $\mathrm{M} \& \mathrm{O})$

\section{Support to USGS}

hydrological investigations (M\&O), performance assessment, and geoscience support
NVO Contracting

Officer's

DE-AI08-86NV10522/

Representative/TBD

C. Gertz and N. Aquilina/T. Blejwas

TBD

DP00789/Oct 88-Sep 90

C. Gertz and N. Aquilina/R. Herbst

ALENG36/Oct 87-Sep 92

C. Gertz and N. Aquilina/L. Jardine

NV Management agreement dated 2/3/86/

Oct 87-Sep 92

C. Gertz/L. Hayes/

P. Witherspoon
SF00098/Sep 87-Sep 92 (five agreements) 
CONTRACTS AND AGREEMENTS (continued)

\begin{tabular}{|c|c|c|c|}
\hline ORGANIZATION & FUNCTION (TYPE) & $\begin{array}{l}\text { BRANCH CHIEF/ } \\
\text { YMP OFFICER }\end{array}$ & $\begin{array}{l}\text { CONTRACT NUMBER/ } \\
\text { DATE }\end{array}$ \\
\hline $\begin{array}{l}\text { 22. Argonne National } \\
\text { Laboratory }\end{array}$ & $\begin{array}{l}\text { Materials Integration/Study } \\
\text { Plan Review } \\
\text { (Support Services) }\end{array}$ & S. Brocoum & $\begin{array}{l}\text { DB-01-04-02/ } \\
\text { DB-01-04-05 }\end{array}$ \\
\hline $\begin{array}{l}\text { 23. Chicago Operations/BMI/ } \\
\text { MACTEC }\end{array}$ & $\begin{array}{l}\text { Site Char. Study Plan Review } \\
\text { (Support Services) }\end{array}$ & S. Brocoum & $\begin{array}{l}\text { CH10139 (DB-01-04-122) } \\
\text { CH10415 }\end{array}$ \\
\hline $\begin{array}{l}\text { 24. Oak Ridge National } \\
\text { Laboratory }\end{array}$ & $\begin{array}{l}\text { Geoscience Technical } \\
\text { Support (Support Services) }\end{array}$ & S. Brocoum & AC05-84OR21400 \\
\hline $\begin{array}{l}\text { 25. Pacific Northwest } \\
\text { Laboratory }\end{array}$ & $\begin{array}{l}\text { Performance assessment and } \\
\text { geoscience support } \\
\text { (Support Services) }\end{array}$ & S. Brocoum & AC06-76RL01830 \\
\hline $\begin{array}{l}\text { 26. Lawrence Livermore } \\
\text { National Laboratory }\end{array}$ & $\begin{array}{l}\text { Waste package design, } \\
\text { material, environment and } \\
\text { performance assessment } \\
\text { (Support Services) }\end{array}$ & TBD/TBD & Mgt. Agreement \\
\hline
\end{tabular}

Note: This listing implies that there is only one contract per contractor, but administration is generally more complicated. Each contractor must apply a uniform QA program in accordance with the QARD/QAPD and the terms of their contracts. 


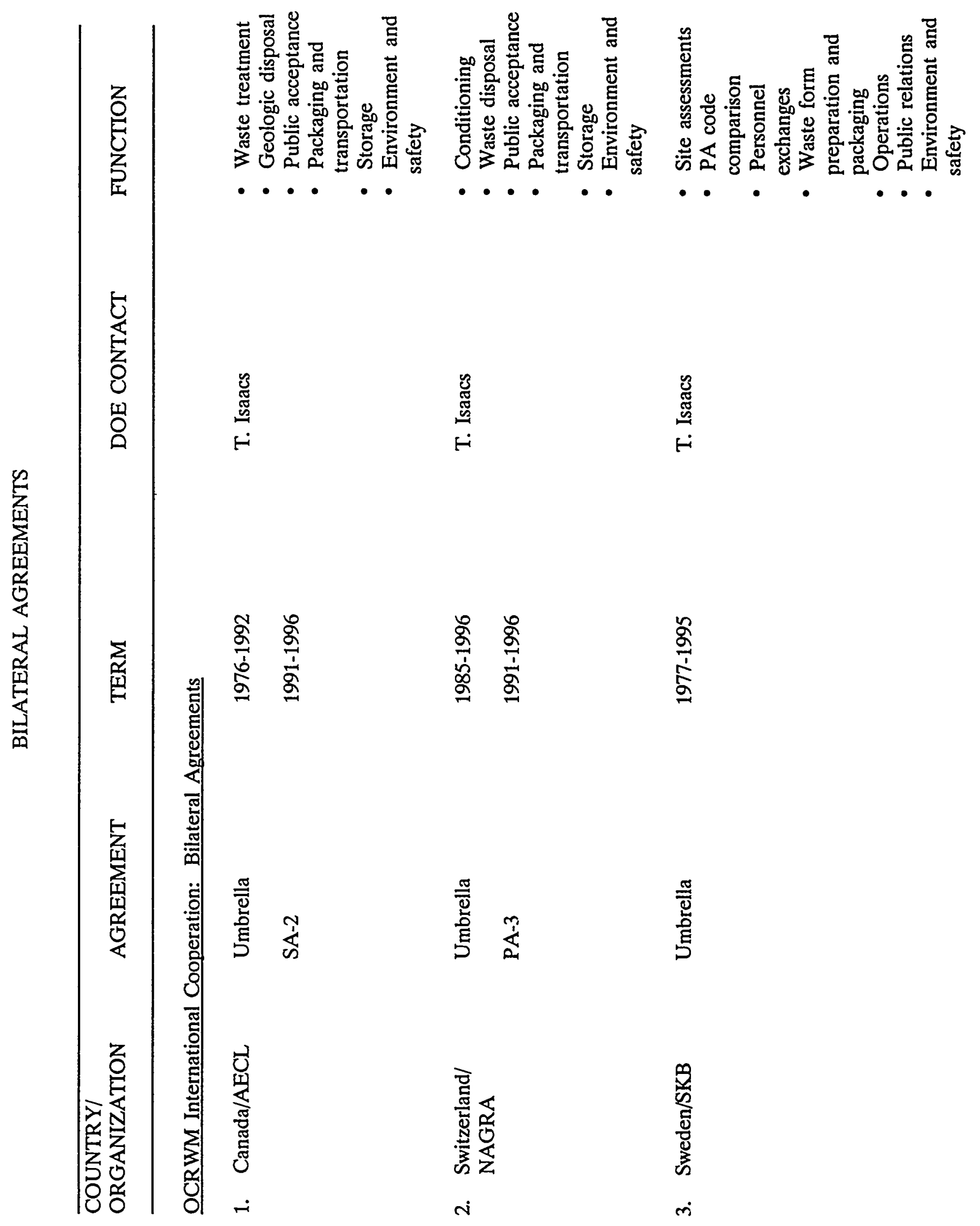


BILATERAL AGREEMENTS

\begin{tabular}{|c|c|c|c|c|c|}
\hline \multicolumn{2}{|c|}{$\begin{array}{l}\text { COUNTRY/ } \\
\text { ORGANIZATION }\end{array}$} & \multirow{2}{*}{$\begin{array}{l}\text { AGREEMENT } \\
\text { Umbrella }\end{array}$} & \multirow{2}{*}{$\begin{array}{l}\text { TERM } \\
1981-1994\end{array}$} & \multirow{2}{*}{$\begin{array}{l}\text { DOE CONTACT } \\
\text { T. Isaacs }\end{array}$} & \multirow{2}{*}{ 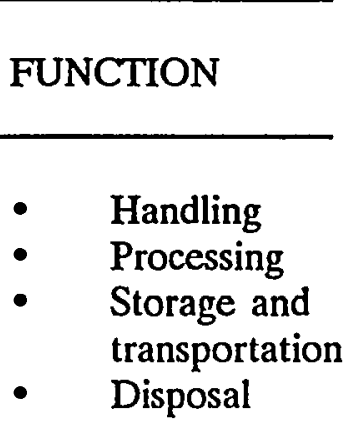 } \\
\hline 4. & $\begin{array}{l}\text { Belgium/CEN/ } \\
\text { SCK }\end{array}$ & & & & \\
\hline 5. & France/CEA & Umbrella & $1983-1993$ & $\begin{array}{l}\text { J. Coleman/ } \\
\text { T. Isaacs }\end{array}$ & $\begin{array}{ll}- & \text { Handling } \\
- & \text { Processing } \\
- & \text { Storage and } \\
& \text { transportation } \\
- & \text { Disposal }\end{array}$ \\
\hline 6. & $\begin{array}{l}\text { Federal } \\
\text { Republic of } \\
\text { Germany/BMFT }\end{array}$ & Umbrella & $\begin{array}{l}\text { 1974-1989 } \\
\text { (renewal } \\
\text { pending) }\end{array}$ & $\begin{array}{l}\text { J. Coleman/ } \\
\text { T. Isaacs }\end{array}$ & $\begin{array}{ll}- & \text { Handling } \\
- & \text { Processing } \\
- & \text { Storage and } \\
& \text { transportation } \\
- & \text { Disposal }\end{array}$ \\
\hline 7. & Japan/PNC & Umbrella & 1986-1996 & $\begin{array}{l}\text { J. Coleman/ } \\
\text { T. Isaacs }\end{array}$ & $\begin{array}{ll}- & \text { Handling } \\
-\quad & \text { Processing } \\
-\quad & \text { Storage and } \\
\text { transportation } \\
\text { - } & \text { Disposal }\end{array}$ \\
\hline 8. & $\begin{array}{l}\text { United } \\
\text { Kingdom/ } \\
\text { UKAEA }\end{array}$ & Umbrella & $1986-1991$ & $\begin{array}{l}\text { J. Coleman/ } \\
\text { T. Isaacs }\end{array}$ & $\begin{array}{ll}- & \text { Handling } \\
- & \text { Processing } \\
- & \text { Storage and } \\
\text { transportation } \\
\text { - } & \text { Disposal }\end{array}$ \\
\hline
\end{tabular}


BILATERAL AGREEMENTS

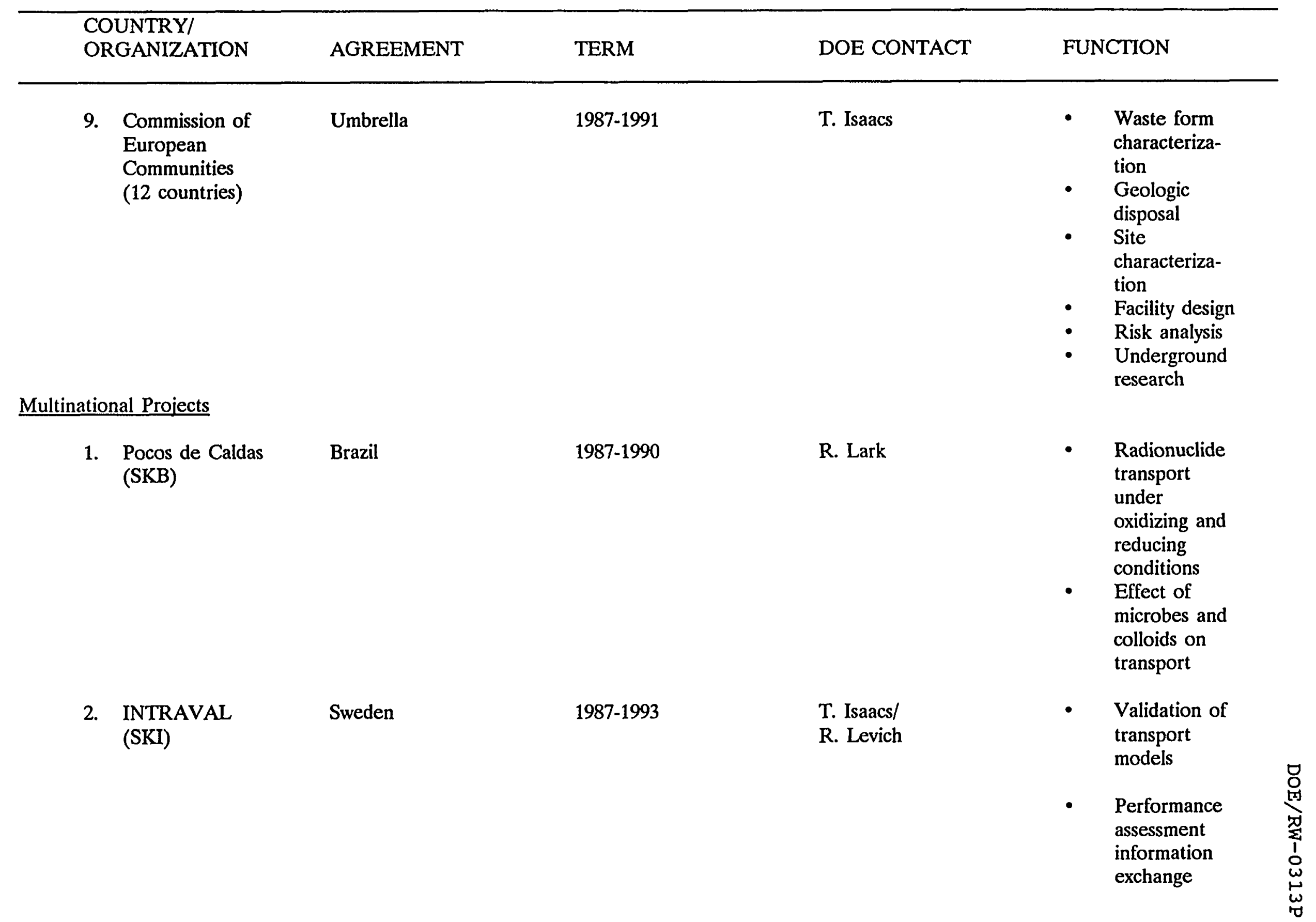


BILATERAL AGREEMENTS

PROJECT

LOCATION

TERM

DOE CONTRACT

FUNCTION

3. OECD/NEA

(23 Countries)

France

Ongoing

T. Isaacs

- Coordinate HLW activities

- Support management and demonstration projects

- Improve national programs through cooperation

- Sponsor advisory groups

3A. STRIPA;

Phase III

Sweden

1986-1991

W. Danker/

(OECD/NEA)

R. Levich

- Site

characterization and validation

- Instrumentation development

- Radionuclide transport and rock mass sealing

4. IAEA

(113 Countries)

Austria

Ongoing

B. Thomas/

T. Isaacs

- Waste management activities to protect the environment

- Preparation of standards, criteria, and codes 
APPENDIX C

LIST OF ACRONYMS 


\section{ACRONYMS}
BA Budget Authority
BO Budget Outlay
CFR Code of Federal Regulations
DEIS Draft Environmental Impact Statement
DOE Department of Energy

$\begin{array}{ll}\text { EA } & \text { Environmental Assessment } \\ \text { EIS } & \text { Environmental Impact Statement } \\ \text { EMMP } & \text { Environmental Monitoring and Mitigation Plan } \\ \text { EPA } & \text { Environmental Protection Agency } \\ \text { ER } & \text { Environmental Report } \\ \text { ESAAB } & \text { Energy Systems Acquisition Advisory Board } \\ \text { ESAR } & \text { Energy Systems Acquisition Review } \\ \text { ESF } & \text { Exploratory Studies Facility } \\ & \\ \text { FEIS } & \text { Final Environmental Impact Statement } \\ \text { FY } & \text { Fiscal Year }\end{array}$

HLW High Level Waste

KD Key Decision

$\begin{array}{ll}\text { LA } & \text { License Application } \\ \text { LAD } & \text { License Application Design }\end{array}$

MGDS Mined Geologic Disposal System

MOA Memorandum of Agreement

MOU Memorandum of Understanding

MRS Monitored Retrievable Storage

MSA Major Systems Acquisition

NEPA National Environmental Policy Act of 1969

NRC Nuclear Regulatory Commission

NTS Nevada Test Site

NVO Nevada Operations Office

NWPA Nuclear Waste Policy Act of 1982

NWTRB Nuclear Waste Technical Review Board 
OCRWM Office of Civilian Radioactive Waste Management

OGD Office of Geologic Disposal

PMP Project Management Plan

PMS Program Management System

QA Quality Assurance

QAPD Quality Assurance Program Description

QARD Quality Assurance Requirements Document

SAR Safety Analysis Report

SCP Site Characterization Plan

SNF Spent Nuclear Fuel

SRR Site Recommendation Report

SSR Site Suitability Report

Title I Preliminary Design

Title II Definitive or Final Design

TEC Total Estimated Cost

TPC Total Project Cost

TPT -Testing Prioritization Task

TSD Technical Support Documentation

WBS Work Breakdown Structure

WMSD Waste Management System Description

WMSR Waste Management System Requirements

YMP Yucca Mountain Site Characterization Project

YMPO Yucca Mountain Site Characterization Project Office 


\section{APPENDIX D}

TECHNICAL, COST, AND SCHEDULE BASELINES AND CHANGE CONTROL THRESHOLDS 
TABLE D-1. YUCCA MOUNTAIN SITE CHARACTERIZATION PROJECT SUMMARY OF BASELINE INFORMATION

Technical (Scope) Baselines

\begin{tabular}{|c|c|c|c|}
\hline $\begin{array}{c}\text { Acquisition Executive } \\
\text { (Level O) }\end{array}$ & $\begin{array}{l}\text { Secretarial/Program } \\
\text { (Level 1) }\end{array}$ & $\begin{array}{l}\text { Project } \\
\text { (Level 2) }\end{array}$ & $\begin{array}{c}\text { Participant/Contractor } \\
\text { (LeveI 3) }\end{array}$ \\
\hline $\begin{array}{l}\text { Surface and subsurface } \\
\text { activities (including } \\
\text { construction of } \\
\text { Exploratory Studies } \\
\text { Facilitios) required to } \\
\text { characterize the Yucca } \\
\text { Mountain candidate site } \\
\text { and provide data required } \\
\text { for ovaluation of } \\
\text { suitability of the site } \\
\text { for development of a } \\
\text { high-level radioactive } \\
\text { waste rL,ository, and if } \\
\text { sultable to produce a } \\
\text { License Application. } \\
\text { (See YMP Project Plan, } \\
\text { Section 2.4) }\end{array}$ & $\begin{array}{l}\text { Reference: } \\
\text { - Waste Management } \\
\text { Systems Requirements } \\
\text { (WuSR) Document, } \\
\text { Volume I: General } \\
\text { Requirements, Rev. 1, } \\
\text { 10/90 } \\
\text { WHSR Document, Volume } \\
\text { IV: Mined Geologic } \\
\text { Disposal System } \\
\text { Requirements, Rev. 1, } \\
\text { 1/81 }\end{array}$ & 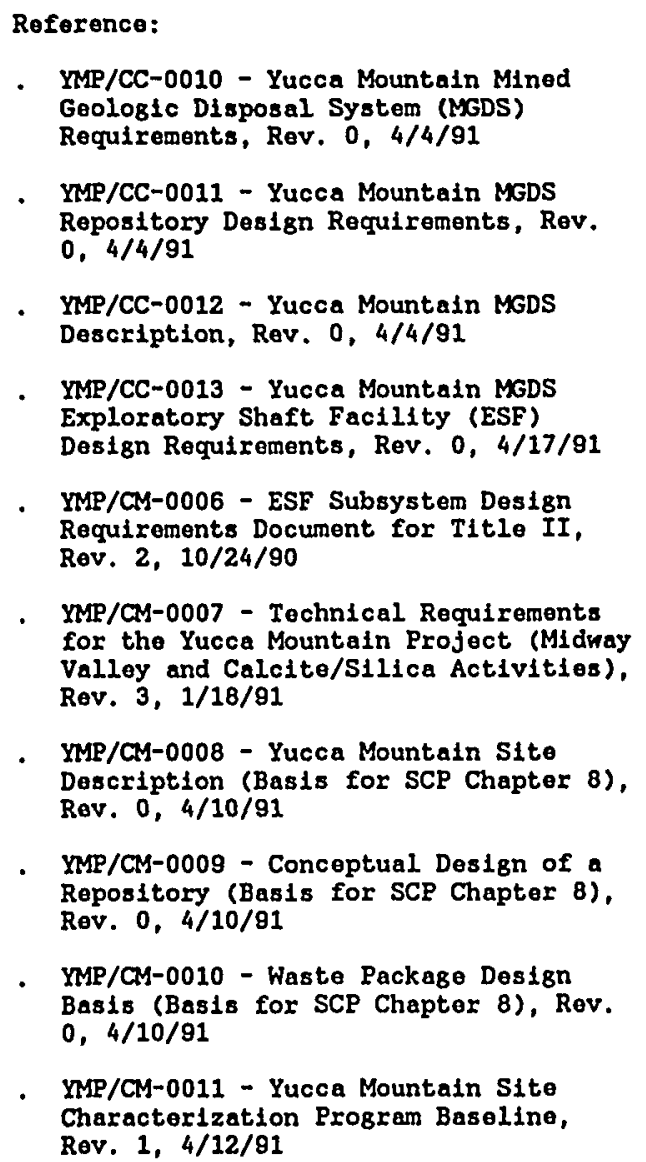 & $\begin{array}{l}\text { Tochnical (scope) baselines } \\
\text { ostablished in the DOE Plannins } \\
\text { and Control System (PACS) at } \\
\text { the participant/contractor } \\
\text { level. Project Division } \\
\text { Directors control changes to } \\
\text { these baselines. }\end{array}$ \\
\hline
\end{tabular}


TABLE D-1. YUCCA MOUNTAIN SITE CHARACTERIZATION PROJECI SUMMARY OF BASELINE INFORMATION (contInUed) Schedule Baseline

\begin{tabular}{|c|c|c|c|}
\hline $\begin{array}{c}\text { Acquisition Executive } \\
\text { (Level O) }\end{array}$ & $\begin{array}{l}\text { Secretarial/Program } \\
\text { (Leve1 1) }\end{array}$ & $\begin{array}{l}\text { Project } \\
\text { (Leve1 2) }\end{array}$ & $\begin{array}{c}\text { Participant/Contractor } \\
\text { (Level 3) }\end{array}$ \\
\hline $\begin{array}{l}\text { RYI08 - Start New } \\
\text { Surface-Based Testing, } \\
1 / 21 / 92 \text { (KD-X) } \\
\text { R6101 - Start Final ESF } \\
\text { Title II Destgn, 10/1/91 } \\
(\text { KD-2) }\end{array}$ & $\begin{array}{l}\text { Reference: } \\
\text { Program Cost and } \\
\text { Schedule Baseline, } \\
\text { DOE/RW-0253, Rev. 2, } \\
\text { 11/91. }\end{array}$ & $\begin{array}{l}\text { Reference: } \\
\text { YMP Cost and Schedule Baseline, } \\
\text { YMP/CM-0015, Rev. 2, 11/91. }\end{array}$ & $\begin{array}{l}\text { Schedule baselines established } \\
\text { in the DOE Planning and Contro } \\
\text { System (PACS) at the } \\
\text { partlclpant/contractor level. } \\
\text { Project Division Directors } \\
\text { control changes to these } \\
\text { baselines. }\end{array}$ \\
\hline
\end{tabular}

RM652 - Start ESF Portal

Construction, $11 / 30 / 92$

(KD-3)

R6610 - Start ESF In Situ

Test Phase, 9/30/95 (KD-

4)

RM458 - Start Repository

LA Design, 6/30/96 (KD-

1A)

R'5151 - Issue Draft

Environmental Impact

Statement, 10/30/99

R5210 - Notify State of

Proposed Site Selection,

$10 / 30 / 99$

R5200 - Issue Site

Recommendation Report to

President, 4/30/01

R5181 - Submit License

Application to NRC

$10 / 30 / 0$

NOTE:

KD - Key Decision polnt requiring ESAAB approval prior to starting work 
TABLE D-1. YUCCA MOUNTAIN SITE CHARACTERIZATION PROJECT SUMMARY OF BASELINE INFORMATION (continued)

Cost Baseline

\begin{tabular}{|c|c|c|c|}
\hline $\begin{array}{c}\text { Acquisition Executive } \\
\text { (Level o) }\end{array}$ & $\begin{array}{l}\text { Secretartal/Program } \\
\text { (Level 1) }\end{array}$ & $\begin{array}{l}\text { Project } \\
\text { (Level 2) }\end{array}$ & $\begin{array}{c}\text { Participant/Contractor } \\
\text { (Level 3) }\end{array}$ \\
\hline $\begin{array}{l}\text { TPC }-\$ 6.3 \mathrm{~B}^{*} \\
\text { (Escalated Costs) }\end{array}$ & $\begin{array}{l}\text { Reference: } \\
\text { Program Cost and } \\
\text { Schedule Baseline, } \\
\text { DOE/RW-0253, Rev. 2, } \\
\text { 11/91 }\end{array}$ & $\begin{array}{l}\text { Reference: } \\
\text { YMP Cost and Schedule } \\
\text { Baseline, YMP/CM-0015, } \\
\text { Rev. 2, 11/91. }\end{array}$ & $\begin{array}{l}\text { Cost baselines established in } \\
\text { the DOE Planning and Control } \\
\text { System (PACS) at the } \\
\text { particlpant/contractor lovel. } \\
\text { Project Division Directors } \\
\text { control changes to these } \\
\text { baselines. }\end{array}$ \\
\hline
\end{tabular}

TPC include costs from January 1983 through Ifcense application. B a billion 
TABLE D-2. YUCCA MOUNTAIN SITE CHARACTERIZATION PROJECT SUMMARY OF CHANGE CONTROL THRESHOLDS

\begin{tabular}{|c|c|c|c|c|}
\hline & $\begin{array}{l}\text { Acquisition } \\
\text { Executive } \\
\text { (Level } 0 \text { ) }\end{array}$ & $\begin{array}{l}\text { Secretarial/ } \\
\text { Program } \\
\text { (Level }\end{array}$ & $\begin{array}{l}\text { Project } \\
\text { (Level 2) }\end{array}$ & $\begin{array}{c}\text { Rarticipant/Contractor } \\
\text { (Level 3) }\end{array}$ \\
\hline $\begin{array}{l}\text { TECHNICAL } \\
\text { (SCOPE) }\end{array}$ & $\begin{array}{l}\text { All scope changes } \\
\text { impacting Level } 0 \text { scope }\end{array}$ & $\begin{array}{l}\text { All scope changes } \\
\text { Impacting Level } 1 \text { scope }\end{array}$ & $\begin{array}{l}\text { All scope changes } \\
\text { impacting Level } 2 \text { scope }\end{array}$ & $\begin{array}{l}\text { Project Diviston } \\
\text { Directors control all } \\
\text { scope changes not } \\
\text { lmpacting Level } 0,1 \text {, } \\
\text { or } 2 \text {. }\end{array}$ \\
\hline SCHEDULE & $\geq 6$ months & $\geq 3$ months & $\geq 3$ months & $\begin{array}{l}\text { Project Division } \\
\text { Director thresholds } \\
\text { less than Level } 2 .\end{array}$ \\
\hline $\cos T$ & $\begin{array}{l}\geq \$ 50 \text { million, but no } \\
\text { Impact on TPC, or } \\
\text { Scope. Change proposal } \\
\text { submitted to PR-1 for } \\
\text { disposition. } \\
\geq \$ 50 \text { million, with } \\
\text { impact on TPC, or } \\
\text { Scope. Change proposal } \\
\text { submitted to ESAAB BCCB } \\
\text { for approval. }\end{array}$ & $\begin{array}{l}\geq \$ 25 \text { million } \\
\text { (WBS Level 2) }\end{array}$ & $\begin{array}{l}\geq \$ 15 \text { mtllion or } 10 x \text { of } \\
\text { TPC (WBS Level } 3 \text { ) } \\
\geq \$ 1 \text { million or } 15 \% \text { of } \\
\text { current year (WBS Level } \\
4 \text { ) }\end{array}$ & $\begin{array}{l}\text { Project Division } \\
\text { Director thresholds } \\
\text { less than Level } 2 \text {, }\end{array}$ \\
\hline
\end{tabular}

\section{Reference:}

Level O: DOE Notice 4700.4

Leve1 1: Program Cost and Schedule Baseline, DOE/RW-0253, Rev, 2

Level 2: Yucca Mountain Site Characterization Project Procedure AP-3.7, Rev. 2. 


\section{APPENDIX E}

FUNDING AND MANPOWER

REQUIREMENTS, FY83-FY92 
FUNDING AND MANPOWER REQUIREMENTS, FY83-FY92

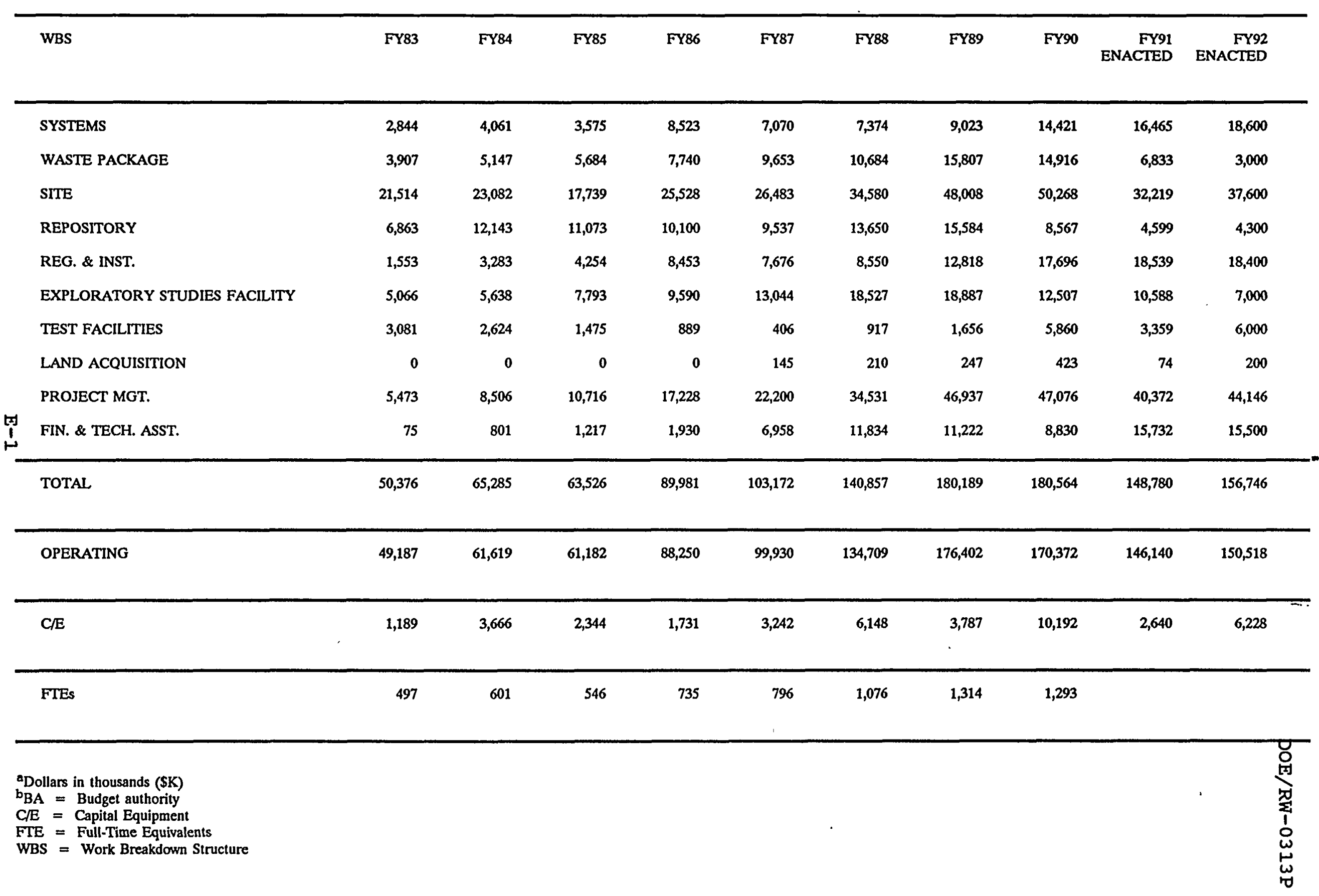

